\title{
PRIMJENA I TUMAČENJE POREZNOG PRAVA: TEORIJSKO-NORMATIVNE OSNOVE
}

Doc. dr. sc. Stjepan Gadžo*

UDK: 340.132.6::336.221.2.01

DOI: $10.3935 /$ zpfz.70.23.07

Pregledni znanstveni rad

Primljeno: srpanj 2020.

Temeljni je cilj rada izložiti teorijsko-normativne osnove primjene i tumačenja poreznog prava. Drugim riječima, istražuju se referencijalna uporišta o kojima primjenjivači poreznih normi moraju voditi računa, neovisno o specifičnostima nacionalnog poreznopravnog okvira. Pri tome se naglasak ipak stavlja na metodologiju primjene poreznog prava u državama kontinentalnog pravnog kruga, u koje se ubraja i Hrvatska. Imajući u vidu često korištenje privatnopravnih pojmova u poreznim propisima, posebna se pozornost posvećuje istraživanju međuodnosa poreznog i drugih grana prava. Nakon uvodnih razmatranja, u drugom dijelu rada sadržan je sažeti prikaz temeljnih nalaza opće teorije prava o metodologiji pravnog tumačenja. U trećem se dijelu kritički preispituje teza o "posebnosti" poreznog prava, a u četvrtom se ocrtava opći okvir tumačenja poreznih normi. Peti dio posvećen je gospodarskom pristupu kao najvažnijoj metodološkoj posebnosti tumačenja poreznih propisa. Šesti, posljednji dio rada, sadržava zaključna razmatranja.

Ključne riječi: porezno pravo, tumačenje prava, gospodarski pristup, primjena pravne norme, ciljno tumačenje

\section{UVOD}

Primjena pravnih normi temeljni je zadatak pravnika praktičara, i onih koji obavljaju pravnu vlast (suci, sudski savjetnici, državni odvjetnici, službenici u javnopravnim tijelima), i onih koji u pravnom životu djeluju bez prerogativa

* Dr. sc. Stjepan Gadžo, docent Pravnog fakulteta Sveučilišta u Rijeci, Hahlić 6, 51 000 Rijeka; sgadzo@pravri.hr;

ORCID ID: orcid.org/0000-0002-1905-5330 
javne vlasti (odvjetnici, korporativni pravnici i dr.). ${ }^{1}$ Metodologija primjene pravnih normi ujedno je i tradicionalni predmet istraživanja pravne znanosti. Štoviše, kako primjećuje Vranken, upravo se u pristupu primjeni prava, odnosno pravnom rasuđivanju (engl. legal reasoning) ogleda svojevrsno "trojstvo" pravne znanosti, (sudačke) prakse te obrazovanja budućih pravnika. ${ }^{2} \mathrm{U}$ prilog navedenoj tezi svjedoči i uključivanje posebnih kolegija posvećenih metodologiji primjene prava u kurikule pravnih studija. ${ }^{3}$

U svakom slučaju, primjena pravne norme od strane osoba sa stručnim pravnim obrazovanjem obuhvaća skup više ili manje složenih intelektualnih postupaka čiji je glavni cilj utvrditi mogu li se konkretne životne situacije (činjenična stanja) podvesti pod apstraktno izražene dijelove pravne norme te tako izazvati određene pravne posljedice. ${ }^{4}$ Visković razlaže pet osnovnih faza procesa primjene pravne norme: (i) prepoznavanje jednoga generičkog ili individualnog društvenog odnosa kao pravno relevantnog odnosa; (ii) utvrđivanje važećih normativnih pravnih akata koji taj pravno relevantan odnos reguliraju; (iii) razumijevanje normativnih pravnih akata radi sastavljanja pravnih normi iz njih; (iv) utvrđivanje činjenica od kojih je sastavljen generički ili individualni pravni odnos i njihovo kvalificiranje apstraktnim ili konkretnim normativnim značenjima; (v) izvršavanje odnosno jezično izjavljivanje novog pravnog akta, normativnog ili nenormativnog, u skladu s pravnom normom. ${ }^{5}$

1 To u smislu Viskovićeva pojma "stručnih pravnih operatora”, tj. pravno obrazovanih subjekata koji sudjeluju profesionalno u pravnom procesu i čije tumačenje prava ima kvalitete potpunosti, preciznosti i pouzdanosti. Visković razlikuje dvije podvrste stručnih pravnih operatora, upravo polazeći od kriterija imaju li ili nemaju pravnu vlast. Vidi Visković, N., O tumačenju pravnih akata, Zbornik Pravnog fakulteta u Zagrebu, vol. 31, br. 3-4, 1981., str. 373 - 374.

2 Vidi Vranken, J., Exciting Times for Legal Scholarship, Recht en Methode in onderzoek en onderwijs, vol. 2, br. 2, 2012., str. $44-45$.

3 U Hrvatskoj je to, nažalost, još uvijek više iznimka no pravilo. Ipak, isticanje potrebe za osuvremenjivanjem kurikula u smjeru ojačavanja praktične dimenzije pravnog obrazovanja izraženo je i u drugim, razvijenijim državama. Vidi ibid., str. 45.

4 Prema Tipke, K.; Lang, J., Steuerrecht, Verlag Dr. Otto Schmidt, Köln, 1996., str. 137. Usporedi Bydlinski, F., Pravna metodologija: Osnovi nauke o pravnim metodama, CID, Podgorica, 2011., str. $14-15$.

5 Visković, op. cit. u bilj. 1, str. 369. Usporedi sistematizaciju primjene pravnih propisa izloženu u Lončarić-Horvat, O., Oporezivanje u skladu s načelima pravne države, u: Jelčić, Bo. i dr., Financijsko pravo i financijska znanost, Narodne novine, Zagreb, 2008. str. 536. 
U primjeni pravnih normi središnje mjesto ima djelatnost (pravnog) tumačenja (engl. legal interpretation; njem. Rechtsauslegung). ${ }^{6}$ Naime, tumačenjem se otkriva značenje odredaba normativnih pravnih akata (pravnih odredaba) s pomoću kojih su izraženi pojedini dijelovi pravne norme. ${ }^{7} \mathrm{U}$ tom smislu glavni je cilj tumačenja utvrditi i razjasniti značenje riječi koje čine građu pravnih odredaba. ${ }^{8}$ U vidu gore navedene sistematizacije, Visković primjećuje da je misaoni postupak tumačenja prisutan u svim fazama primjene pravne norme, iako je u juridičkom smislu najspecifičniji i najteži upravo u fazi navedenoj pod (iii), tj. prilikom otkrivanja normativnih značenja danih u pravnim odredbama radi sastavljanja pravne norme. ${ }^{9}$ Stoga stoji i zaključak o tumačenju kao preduvjetu primjene pravne norme. ${ }^{10}$ Riječima slavnog britanskog pravnog povjesničara Fredericka Pollocka, "pravo bez tumačenja je tek beživotni kostur, a tumačenje ga pretvara u živi organizam". ${ }^{11}$ Iako tumačenje uvijek ima spoznajnu funkciju, bez obzira na to koji subjekt tumači normativne akte, za cjelokupni je pravni poredak posebno važno tumačenje koje je obvezujuće i konkretno (kazuističko), tj. koje je usmjereno upravo primjeni pravne norme na konkretna činjenična stanja. ${ }^{12}$ Naime, na taj način dolazi do usmjeravanja ljudskog ponašanja i regulacije društvene stvarnosti in concreto, što se može opisati i stvaranjem (ili: do-stvaranjem) prava. ${ }^{13} \mathrm{U}$ suvremenim državama, čiji se pravni sistemi temelje na konceptu "pravne države" (njem. Rechtsstaat) ili "vladavine prava" (engl. rule of $l a w)^{14}$, ovakvo je tumačenje jedna od temeljnih zadaća sudova i upravnih organa.

${ }_{6}$ Krever, R.; Van Brederode, R. F., Legal interpretation of tax law: a reflection on methods and issues, u: Van Brederode, R. F.; Krever, R. (ur.), Legal Interpretation of Tax Law, Kluwer Law International, Alphen aan den Rijn, 2014., str. 1. Usporedi Đerđa, D., Neke primjedbe o tumačenju prava, Zbornik Pravnog fakulteta u Rijeci, vol. 23, br. 2, 2002., str. $641-642$.

7 Prema Visković, N., Teorija prava i države, Birotehnika, Zagreb, 2001., str. 241. Za detaljniju raspravu o diferencijaciji pravnih odredaba kao objektu tumačenja i pravnih normi kao rezultatu tumačenja vidi Visković, op. cit. u bilj. 1, str. 370 - 372.

8 Prema Tipke i Lang, op. cit. u bilj. 4, str. 140.

9 Visković, op. cit. u bilj. 1, str. 370.

10 Vidi Đerđa, op. cit. u bilj. 6, str. 615.

11 Citirano u: Vogenauer, F., Sources of Law and Legal Method in Comparative Law, Max Planck Institute for European Legal History Research Paper Series, No. 2020-04, str. 2.

12 Prema Visković, op. cit. u bilj. 7, str. 245.

13 Vidi Krever i Van Brederode, op. cit. u bilj. 6, str. 1 - 2. O pojmu "do-stvaranja prava" vidi Visković, op. cit. u bilj. 7, str. $242-243$.

14 Za nijansiranje ovih pojmova vidi Čepulo, D., Vladavina prava i pravna država europska $i$ hrvatska pravna tradicija i suvremeni izazovi, Zbornik Pravnog fakulteta $\mathrm{u}$ Zagrebu, vol. 51, br. 6, 2001., str. 1338 - 1344. 
Štoviše, vrijedi naglasiti da oživotvorenje nekih od osnovnih postulata pravne države, poput načela zakonitosti, jednakosti građana i pravne sigurnosti, u značajnoj mjeri ovisi o pravilnoj primjeni pravnih normi te o ispravnom i metodičkom pristupu tumačenju normativnih akata. ${ }^{15}$ Navedeno ima osobitu važnost za one dijelove pravnog sustava kojima se zadire u subjektivna prava pojedinaca ili im se, pod plaštom javnog interesa, nameću kakve obveze. ${ }^{16} \mathrm{~S}$ obzirom na to da fenomen oporezivanja ( $\mathrm{tj}$. nametanja i ubiranja poreza) pretpostavlja umanjenje gospodarske snage (u pravnom smislu: imovine ${ }^{17}$ ) građana u korist države, bez neposredne protučinidbe, primjena poreznih normi i tumačenje poreznih propisa izazivaju niz i u teorijskom i u praktičnom smislu važnih pitanja.

Primjerice, već njemački i talijanski pisci iz prve polovice 20. stoljeća, danas smatrani klasicima formativnog razdoblja poreznopravne znanosti, posvećuju itekakvu pozornost istraživanju metodologije primjene poreznih propisa, osobito s ciljem rasvjetljavanja pozicije poreznog prava unutar cjelokupnog pravnog sustava. Upravo je teza o postojanju posebnog metodološkog aparata za primjenu poreznog prava, u čijem središtu leži doktrina tzv. gospodarskog pristupa $^{18}$, isticana u prilog emancipaciji poreznog prava kao pravne discipline autonomne u odnosu na druge, tradicionalnije pravne grane, poput građanskog prava i upravnog prava. ${ }^{19} \mathrm{Na}$ praktičnoj razini dovoljno je istaknuti kako se značajan udio poreznih sporova zapravo može okarakterizirati sporovima o tumačenju odredaba poreznih propisa, pri čemu porezni obveznici s jedne te porezna tijela s druge strane pokušavaju dokazati valjanost jednog specifičnog rezultata tumačenja, posežući pritom za različitim metodama ili argumentima. Štoviše, u hrvatskoj su pravnoj praksi nerijetko apostrofirani ozbiljni nedostaci u pristupu koji porezna tijela i sudovi zauzimaju u tumačenju poreznih propisa, obilježenim pretjeranim formalizmom i arbitrarnošću. ${ }^{20} \mathrm{U}$ posljednjih desetak

15 Vidi Lončarić-Horvat, op. cit. u bilj. 5, str. 536.

16 Vidi Bydlinski, op. cit. u bilj. 4, str. 20 - 21. U smislu navedenog vrijedi naglasiti kako se u njemačkoj pravnoj doktrini porezno pravo, kao dio javnog prava, ubraja u tzv. intervencijsko pravo (njem. Recht der Eingriffsverwaltung). Vidi Tipke i Lang, op. cit. u bilj. 4 , str. 4 .

$17 \mathrm{O}$ ovomu detaljnije vidi Arbutina, H., Ustavna i nadnacionalna ograničenja ovlaštenja na oporezivanje, Zbornik Pravnog fakulteta u Zagrebu, vol. 62, br. 5-6, 2012., str. 1286.

18 O tomu detaljnije infra, poglavlje 5.

19 Detaljnije vidi Popović, D., Poresko pravo, Univerzitet u Beogradu - Pravni fakultet, Beograd, 2018., str. $24-34$.

20 Vidi, primjerice, Peček, R., Formalizam i arbitrarnost u nekim poreznim postupcima, Informator, br. 6394, od 30. 11. 2015., str. 17 - 19; Rogić Lugarić, T.; Bogovac, J., Pravni status poreznih izdataka: stanje i perspektive, u: Bratić, V.; Fabris, M. (ur.), Skrive- 
godina ističe se i niz odluka Ustavnog suda RH, kojima su utvrđene povrede Ustavom zajamčenih prava poreznih obveznika, posebno prava na pravično suđenje (čl. 29. st. l. Ustava $\mathrm{RH}^{21}$ ) zbog pogrešnog tumačenja i primjene mjerodavnih propisa. ${ }^{22}$

Unatoč opisanim teorijskim i praktičnim dilemama, tematika primjene i tumačenja poreznih propisa u domaćoj financijskopravnoj književnosti dosad nije obrađena na sustavan i sveobuhvatan način. ${ }^{23} \mathrm{U}$ tom smislu najpreglednijim prinosom ističe se analiza Lončarić-Horvat, koja - smještajući temu unutar šireg konteksta oporezivanja u skladu s načelima pravne države - prezentira temeljne faze primjene poreznih propisa, uz poseban osvrt na gospodarsko tumačenje, pritom se ipak zadržavajući unutar unaprijed zadanih granica udžbeničkog djela. ${ }^{24}$ Nadalje, udžbeničko djelo Arbutine i Rogić Lugarić, posvećeno prikazu temelja hrvatskog poreznopravnog okvira - s naglaskom na njegovu postupovnu komponentu - sadržava zanimljiv i vrijedan osvrt o načelu gospodarskog pristu$\mathrm{pa}^{25}$, propisanog člankom 11. Općeg poreznog zakona (dalje u tekstu: OPZ). ${ }^{26}$ Ističe se i Šinkovićeva analiza doktrine gospodarskog pristupa, osobito zbog naglašene poredbenopravne dimenzije. ${ }^{27}$

Imajući u vidu navedeno, temeljni je cilj rada izložiti teorijsko-normativne osnove primjene i tumačenja poreznog prava. Drugim riječima, znanstveni se doprinos rada očituje ponajprije $u$ identifikaciji i sistematizaciji referencijalnih uporišta o kojima primjenjivači poreznih normi moraju voditi računa, neovisno

na javna potrošnja: Sadašnjost i budućnost poreznih izdataka, Institut za javne financije, Zagreb, 2012., str. 192.

${ }^{21}$ Narodne novine, br. 56/1990, 135/1997, 08/1998, 113/2000, 124/2000, 28/2001, 41/2001, 55/2001, 76/2010, 85/2010, 05/2014.

22 Vidi, primjerice, odluke Ustavnog suda Republike Hrvatske br. U-III/1133/2012 od 8. travnja 2014., para. 8.2. i 8.3. te br. U-III/4285/2013 od 27. rujna 2016., para. 8.2. i 8.3 .

23 Inozemna je literatura u tom smislu puno bogatija. Vidi, primjerice, Krever i Van Brederode, op. cit. u bilj. 6; Heber, C.; Sternberg, C., Germany, u: Brederode, R. F.; Krever, R. (ur.), Legal Interpretation of Tax Law, Kluwer Law International, Alphen aan den Rijn, 2014., str. 163 - 189; Gassner, W., Interpretation und Anwendung der Steuergesetze: kritische Analyse der wirtschaftlichen Betrachtungsweise des Steuerrechts, Wirtschaftsverlag Dr. Anton Orac, Wien, 1972.

24 Lončarić-Horvat, op. cit. u bilj. 5, str. 536 - 544.

25 Arbutina, H.; Rogić Lugarić, T., Osnove poreznog prava, Narodne novine, Zagreb, 2017., str. 7 - 9 .

26 Narodne novine, br. 115/2016, 106/2018, 121/2019, 32/2020, 42/2020.

27 Šinković, Z., Načelo gospodarskog pristupa činjenicama bitnima za oporezivanje, Zbornik radova Pravnog fakulteta u Splitu, vol. 55, br. 1, 2018., str. 201 - 219. 
o specifičnostima nacionalnog poreznopravnog okvira. To zahtijeva obradu sljedećih istraživačkih potpitanja:

(i) Kakav je međuodnos općeg okvira primjene i tumačenja pravnih normi, načelno primjenjivog u svim pravnim područjima, i posebnih interpretacijskih doktrina razvijenih u okrilju poreznog prava?

(ii) Koja je uloga pojedinih metoda tumačenja pravnih odredaba kad su posrijedi porezni propisi?

(iii) Imajući u vidu često korištenje privatnopravnih pojmova u poreznim propisima, koje je mjesto i značenje tzv. doktrine gospodarskog pristupa (ili gospodarskog tumačenja) za primjenu poreznog prava?

S obzirom na to da su metode tumačenja pravnih odredaba gotovo beziznimno tvorevine sudske prakse i pravne znanosti ${ }^{28}$, glavnina se istraživanja temelji na analizi ovih pravnih izvora u poredbenom kontekstu. Pri tome se naglasak ipak stavlja na metodologiju primjene poreznog prava u državama kontinentalnog pravnog kruga, u koje se ubraja i Hrvatska. Sukladno tomu, rad nema ambiciju predložiti kakav novi (meta)teorijski pristup tumačenju poreznih propisa, već je pragmatično usmjeren: raščlambom temeljnih problema tumačenja poreznih propisa želi se olakšati zadatak službenika poreznih tijela, sudaca i drugih stručnjaka koji ih primjenjuju u praksi. ${ }^{29}$ Pri tome se polazi od pretpostavke da se u sistematizaciji pravnih normi, sučeljavanju različitih koncepata i otklanjanju antinomija te promicanju koherentnog pravnog okvira kriju društveno najkorisniji zadatci (normativističke) pravne znanosti. ${ }^{30}$ Konačno, vrijedi napomenuti kako se, s obzirom na ograničeni opseg rada, izbjegava detaljna analiza hrvatskog normativnog okvira te sudske i administrativne prakse, što svakako zaslužuje

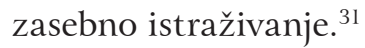

Rad je podijeljen na šest dijelova. Nakon uvoda, u drugom dijelu slijedi sažeti prikaz temeljnih nalaza opće teorije prava o metodologiji pravnog tumačenja. U trećem se dijelu kritički preispituje teza o "posebnosti" poreznog prava, a u

28 Vidi Visković, op. cit. u bilj. 7, str. 247; Bydlinski, op. cit. u bilj. 4, str. 18. Za definiciju metoda tumačenja vidi Đerđa, op. cit. u bilj. 6, str. 628. Za razlikovanje metoda tumačenja od srodnog pojma "argumenata" vidi Visković, N., Argumentacija i pravo, Pravni fakultet u Splitu, Split, 1997., str. $21-22$.

29 Usporedi, za vrijednost ovakvog, pragmatičnog pristupa tematici pravnog tumačenja, Graham, R. N., A Unified Theory of Statutory Interpretation, Statute Law Review, vol. 23, br. 2, 2002., str. 92 .

30 Za detaljniju raspravu o ovomu vidi Vranken, op. cit. u bilj. 2, str. 45 - 47; Núñez Vaquero, Á., Five Models of Legal Science, Revus, vol. 19, 2013., str. 63 - 64.

31 Za kratak pregled vidi Arbutina i Rogić Lugarić, op. cit. u bilj. 25, str. 7 - 9. 
četvrtom se ocrtava opći okvir tumačenja poreznih normi. Peti dio posvećen je gospodarskom pristupu kao najvažnijoj metodološkoj posebnosti tumačenja poreznih propisa. Šesti, posljednji dio rada, sadržava zaključna razmatranja.

\section{OPĆENITO O METODOLOGIJI PRAVNOG TUMAČENJA}

U uvodnom je dijelu naznačeno kako temeljni postulati vladavine prava, a posebice načelo zakonitosti, zahtijevaju da primjenjivači pravnih normi tumače pravne odredbe na metodološki primjeren način. Međutim, već se pri postavljanju pitanja što to konkretno podrazumijeva susreću ozbiljni doktrinarni prijepori. ${ }^{32}$ Naime, u većini pravnih sustava metode ili pravila pravnog tumačenja nisu formalizirana na razini ustavnog ili zakonskog teksta, odnosno sama po sebi nemaju karakter obvezujućih pravnih normi. ${ }^{33}$ Kako ističe Vogenauer, izostanak pisanih, obvezujućih pravila tumačenja u državama se kontinentalnog (romansko-germanskog) pravnog kruga može pripisati i spoznaji zakonodavaca da je gotovo nemoguće na koherentan način zakonski urediti metodologiju tumačenja. ${ }^{34}$ Stoga je razvoj metoda tumačenja pravnih odredaba gotovo $\mathrm{u}$ potpunosti prepušten sudskoj praksi i pravnoj znanosti.

Pritom polazišnu točku predstavlja temeljna podjela metoda ovisno o sredstvu tumačenja, odnosno o kodu s pomoću kojeg tumač pokušava razumjeti značenje pravne odredbe. ${ }^{35} \mathrm{U}$ tom smislu i danas se često polazi od von Savignyeva razlikovanja četiriju "kanona tumačenja” - jezičnog (gramatičkog), sustavnog, povijesnog i ciljnog. ${ }^{36}$ Dakako, pravna je znanost iznjedrila i druge metode ili argumente tumačenja, poput argumenata pravne logike (ili logičkog tumačenja) te metode tumačenja u skladu s ustavom (njem. Verfassungskonforme Auslegung), detaljniji pregled kojih prelazi granice ovog rada. ${ }^{37} \mathrm{~S}$ obzirom na to da pojedine metode međusobno ne stoje ni u kakvom čvrstom hijerarhijskom odnosu $^{38}$, a često vode različitim rezultatima, primjenjivaču pravne norme doista je ostavljen određeni prostor slobode $\mathrm{u}$ izboru metode, tj. odabiru argumenata

\footnotetext{
32 Za kratak pregled vidi Bydlinski, op. cit. u bilj. 4, str. $15-21$. Law International, The Hague, London, New York, 2003., str. 144.

Ibid., str. 629.
} 
kojima obrazlaže vlastitu odluku. ${ }^{39}$ Ipak, kako upozorava Bydlinski, zadatak je suca uvijek tragati za "najbolje obrazloženim rješenjem", bez obzira na to što je, ovisno o odabiru metode tumačenja, moguće ponuditi više rješenja za isti pravni problem. ${ }^{40}$ Štoviše, većina autora prihvaća tezu kako postoji određeni redoslijed kojeg se valja držati prilikom primjene pojedinih metoda, pri čemu jezično tumačenje pravnih odredaba u pravilu predstavlja polaznu točku, nakon čega se pristupa analizi sistemske povezanosti između pravnih normi (sistemsko tumačenje), izvora koji pružaju informacije o društvenim okolnostima koje se mogu označiti kao occasio legis (povijesno tumačenje) te utvrđivanju cilja ili svrhe pojedinih odredbi (ciljno tumačenje). ${ }^{41}$ Zapravo će u najvećem broju slučajeva biti nužno primijeniti dvije metode ili više metoda tumačenja te se u tom smislu govori o nužnom "metodološkom sinkretizmu". ${ }^{2}$ Kako ističe Visković, jezično je tumačenje "gotovo bez izuzetka nužno i početno, dok je u slučajevima težih nejasnoća ciljna argumentacija redovito najmoćnija i odlučujuća". ${ }^{3}$

Posebna vrijednost ciljne (teleološke) metode povezana je s temeljnom funkcijom pravnog tumačenja uopće. Naime, pravila leksikologije, gramatike i sintakse nisu dovoljna za otkrivanje značenja pravnih normi. Naprotiv, mora se imati u vidu da sve riječi koje čine građu pravnih odredaba nužno služe izražavanju i komuniciranju cilja (telosa) pravne norme, a to je uvijek rješavanje sukoba interesa između pojedinaca i pojedinih društvenih skupina, u skladu s vrijednosnim sudom zakonodavca. ${ }^{44}$ Drugim riječima, značenje svake pravne norme neraskidivo je od konteksta koji čini njezina funkcija unutar čitavog pravnog sistema. Tako i Visković ističe da je "od svih mogućih značenja jedne norme najbolje ono koje najpotpunije ostvaruje njezin cilj, razlog njenog postojanja (ratio legis)". ${ }^{45}$ Korak dalje idu Tipke i Lang, ističući kako je pogrešno davati jednaku vrijednost ciljnom tumačenju i drugim metodama, s obzirom da i jezik, pravno-sistemske veze te geneza donošenja propisa zapravo služe utvrđenju cilja norme. ${ }^{46}$ Gledano iz ovog kuta, primjenjivač pravne norme nužno mora voditi

39 Prema Visković, op. cit. u bilj. 7, str. $246-248$.

40 Bydlinski, op. cit. u bilj. 4, str. 18 - 19.

${ }^{4}$ Vidi Tipke i Lang, op. cit. u bilj. 4, str. 136 - 137. Usporedi i još čvršće stajalište o postojanju jasnog redoslijeda primjene pojedinih metoda u Bydlinski, op. cit. u bilj. 4 , str. $96-101$.

42 Koenig, U., Abgabenordnung: AO (3. izd.), C. H. Beck, München, 2014., § 4 para. 94.

43 Visković, op. cit. u bilj. 7, str. 247.

44 Heber i Sternberg, op. cit. u bilj. 23, str. 164 - 165. Usporedi i Visković, op. cit. u bilj. 7, str. 114.

45 Ibid., str. 250.

46 Tipke i Lang, op. cit. u bilj. 4, str. 140. 
računa o njezinu cilju, o kojem ovisi i pitanje u kojoj su mjeri pojedini jezični izrazi sadržani u zakonskom tekstu nejasni ili višeznačni. ${ }^{47}$

U teoriji je, međutim, sporno na koji način valja pristupiti utvrđivanju cilja norme. Općenito se razlikuju dva pristupa: prema subjektivnom pristupu potrebno je utvrditi volju zakonodavca kakva je bila u trenutku donošenja zakona, pri čemu posebnu važnost ima dokumentacija korištena u okviru zakonodavnog postupka; s druge strane, objektivni pristup teži utvrđenju cilja norme ovisno o društvenim okolnostima i vrijednostima u trenutku njezine primjene, neovisno o volji povijesnog normotvorca. ${ }^{48} \mathrm{U}$ tom je smislu praksa Saveznog ustavnog suda SR Njemačke ponudila rješenje na tragu integracije svih četiriju kanona von Savignyja: iako se pravne odredbe načelno moraju tumačiti u skladu s njihovom (objektivnom) svrhom, subjektivna volja povijesnog normotvorca ima prednost pod uvjetom da je jasno izražena u tekstu propisa. ${ }^{49}$

U utvrđivanju objektivne svrhe ili funkcije pravnih odredaba tumaču može uvelike pomoći sistemska metoda te pravila pravne logike. Naime, sistemsko tumačenje podrazumijeva utvrđivanje mjesta pravne norme, kao i odredaba od kojih je sastavljena, unutar pojedinog zakona, ali i unutar cjelokupnog pravnog sustava, te smisleno povezivanje više normi radi boljeg razumijevanja njihova značenja. ${ }^{50}$ Ovdje ulogu mogu imati tzv. vanjski elementi, poput redoslijeda zakonskih članaka ili njihova naziva, koji bi načelno trebali odražavati funkciju pojedinih odredaba. ${ }^{51}$ Primjerice, u strukturi zakonskog teksta opća pravila (lex generalis) obično prethode posebnim pravilima (lex specialis). Na pravno-sistemske poveznice upućuju i u pravnoj doktrini razvijena tzv. kolizijska pravila, kojima se rješavaju proturječnosti ili antinomije unutar pravnog sustava (npr. pravilo lex specialis derogat legi generali). ${ }^{52}$

U svakom slučaju, nepobitnim se čini stajalište da jezična analiza određuje vanjske granice dopuštenih rezultata tumačenja. ${ }^{53}$ Pritom je, kad je riječ o pojedinim jezičnim pojmovima korištenim u pravnim odredbama, korisna teorijska distinkcija između "jezgre pojma” (njem. Begriffskern) i "predvorja

47 Loc. cit.

48 Detaljnije vidi Bydlinski, op. cit. u bilj. 4, str. 31 - 46; Tipke i Lang, op. cit. u bilj. 4, str. 142 - 143.

49 Vidi Heber i Sternberg, op. cit. u bilj. 23, str. 165.

50 Vidi Visković, op. cit. u bilj. 7, str. 253 - 254.

51 Tipke i Lang, op. cit. u bilj. 4, str. 144.

52 Vidi Bydlinski, op. cit. u bilj. 4, str. 30 - 31.

53 Vidi ibid., str. 166; Tipke i Lang, op. cit. u bilj. 4, str. 140. 
pojma" (njem. Begriffshof). ${ }^{54}$ Dok jezgra pojma označava sve objekte koje će svi članovi neke jezične zajednice nedvojbeno podvesti pod opseg pojma, predvorje pojma označava objekte koji se, ovisno o okolnostima, mogu naći i unutar i izvan opsega pojma. U tom smislu dva su rezultata tumačenja problematična: neprimjena pravne odredbe na činjenična stanja koja jasno pripadaju jezgri pojma, kao i primjena odredbe na činjenična stanja koja stoje izvan predvorja ili periferije pojma. Prvi rezultat može biti dopušten samo iznimno, pozivanjem na cilj norme (tzv. teleološka redukcija), dok drugi pripada sferi analogije kao dopunjujućeg stvaranja prava. ${ }^{55}$ Stoga je u praktičnom smislu utvrđivanje cilja odredbe to važnije što je opseg korištenih pojmova širi, tj. što su više ti pojmovi neodređeni. ${ }^{56}$ Bydlinski tako ističe razliku između jednostavnih slučajeva, kod kojih se, uslijed nepostojanja jezičnih i normativno-sistemskih nedoumica, primjenjivač pravne norme ne treba upuštati u detaljniju analizu svih mogućih varijanti tumačenja, od posebno složenih ili teških slučajeva (engl. hard cases), koji zahtijevaju sveobuhvatnu analizu i vaganje svih argumentacijskih linija. ${ }^{57}$

\section{ODBACIVANJE TEZE O POSEBNOSTI POREZNOG PRAVA}

Žarište većine akademskih rasprava o tumačenju poreznog prava upravo je na rasvjetljavanju uloge pojedinih gore navedenih metoda tumačenja, primjenjivih u svim pravnim područjima, u specifičnom kontekstu nametanja i ubiranja poreza. Pritom je osobito složeno pitanje međuodnosa ovog općeg metodološkog okvira s posebnim poreznopravnim doktrinama koje djeluju (i) na interpretacijskoj razini, poput doktrine gospodarskog pristupa ili zahtjeva za restriktivnim (uskim) tumačenjem poreznih zakona. ${ }^{58}$

U tom smislu valja razmotriti i tezu o "posebnosti" poreznog prava. Naime, s obzirom na postojanje specifičnih doktrina koje se koriste prilikom primjene poreznih propisa, moguće je tvrditi kako supra opisane opće postavke pravnog tumačenja imaju manju, ili čak zanemarivu, praktičnu važnost u poreznopravnom

54 Kako je detaljnije opisano u Bydlinski, F., Juristische Methodenlehre und Rechtsbegriff, Springer, Wien, 2011., str. 118 - 119.

55 Vidi Bydlinski, op. cit. u bilj. 4, str. $77-83$.

56 Tipke i Lang, op. cit. u bilj. 4, str. 141.

57 Bydlinski, op. cit. u bilj. 4, str. $96-101$.

58 Za pregled ovih doktrina i argumenata vidi Thuronyi, op. cit. u bilj. 36, str. 136 150; Popović, op. cit. u bilj. 19, str. 52 - 54; Brooks, N., The Logic, Policy and Politics of Tax Law, u: Edgar, T. et al. (ur.), Materials on Canadian Income Tax, Carswell, Scarborough, 2000., pogl. 9.2. 
kontekstu. Tako neki autori začetak teze o poreznopravnom ekscepcionalizmu nalaze još u Justinijanovim Digesta i glasovitom pravilu in dubio contra fiscum. ${ }^{59}$ Suvremeniji, i u praktičnom smislu značajniji, refleks ove doktrine može se prepoznati u judikaturi najviših sudova nekih zemalja (npr. Belgija, Ujedinjeno Kraljevstvo, Australija), gdje se tradicionalno zastupa stav o potrebi restriktivnog tumačenja svih odredaba koje dovode do nastanka oporezivog događaja ili povećanja porezne obveze. ${ }^{60}$ Čini se da u teorijskoj podlozi takvog literalizma u korist poreznog obveznika leži viđenje poreza isključivo kao zahvata države u imovinska prava pojedinaca, koji se pokušava ublažiti restriktivnim tumačenjem pojmova korištenih u zakonu. ${ }^{61}$ Iz perspektive suvremene porezne teorije ovaj se argument ne čini odveć uvjerljivim jer je poreze pogrešno promatrati neovisno o temeljnoj svrsi njihova nametanja, a to je financiranje javnih usluga. ${ }^{62} \mathrm{O}$ drugoj temeljnoj slabosti doslovnog tumačenja poreznih propisa bilo je već riječi ranije: značenje jezičnih izraza korištenih u zakonu ne može se otkriti bez sagledavanja cjelokupnog konteksta, uključujući i cilj poreznopravnih normi. ${ }^{63}$

U svakom slučaju, restriktivni pristup tumačenju poreznih propisa stvara plodno tlo za fenomen zakonite porezne evazije, tj. izbjegavanja plaćanja poreza, s obzirom na to da porezni obveznici mogu odabirom pravnog oblika svojih ekonomskih aktivnosti "zaobići" primjenu odredaba na kojima se temelji porezna obveza. ${ }^{64}$ Stoga se već u prvoj polovici 20. stoljeća u nekim državama javlja ideja o potpuno suprotnom metodološkom pristupu, koji se može označiti ekstenzivnim (širokim), a zapravo polazi od utvrđenja (objektivnog) cilja

59 Vidi Menéndez, A., Justifying Taxes: Some Elements for a General Theory of Democratic Tax Law, Kluwer, Dordrecht, 2001., str. 320; Abreu, A.; Greenstein, R., Tax: Different, Not Exceptional, Administrative Law Review, vol. 71, br. 4, 2019., str. 672 - 673; Popović, op. cit. u bilj. 19, str. 52 - 53.

60 Vidi Thuronyi, op. cit. u bilj. 36, str. 137 - 145. U Ujedinjenom Kraljevstvu do svojevrsnog zaokreta i odbacivanja restriktivnog pristupa tumačenju poreznih propisa dolazi još 1982. godine, nakon odluke Doma lordova u predmetu Ramsay v. IRC. O tomu detaljnije vidi Freedman, J., Interpreting Tax Statutes: Tax Avoidance and the Intention of Parliament, The Law Quarterly Review, vol. 123, br. 1, 2007., str. 52 - 90.

61 Prema Menéndez, op. cit. u bilj. 59, str. 320; Brooks, op. cit. u bilj. 58, pogl. 9.2.2.

62 Menéndez, op. cit. u bilj. 59, str. 321; Popović, op. cit. u bilj. 19, str. 53.

63 Usporedi Krever i Van Brederode, op. cit. u bilj. 6, str. 7 - 8; Brooks, op. cit. u bilj. 58, pogl. 9.2.2.

64 O razlikovanju zakonite i nezakonite porezne evazije vidi Gadžo, S.; Klemenčić, I., Analiza normativnog okvira za sprječavanje zakonitog izbjegavanja poreza u Hrvatskoj: prijedlog izmjena u skladu s pravom Europske unije, Odabrani prijevodi, br. 25, 2014., str. $3-5$. 
poreznopravne norme. ${ }^{65}$ Simbol ovog pristupa jest članak 4. njemačkog zakona o javnim davanjima (Reichsabgabenordnung, dalje u tekstu: RAO) iz 1919., kojim je određeno da se prilikom tumačenja poreznih zakona ima uzeti u obzir njihova svrha, ekonomska važnost i razvoj (društveno-ekonomskih) odnosa. ${ }^{66}$ Izostavljanje izričitog pravila o potrebi za ovakvim tzv. gospodarskim pristupom (njem. wirtschaftliche Betrachtungsweise) u Zakonu o javnim davanjima (Abgabenordnung, dalje u tekstu: AO) iz 1977. prema većini njemačkih autora ne znači da ova metodološka smjernica gubi pravnu snagu, što potvrđuje i ustaljena sudska praksa. ${ }^{67} \mathrm{O}$ normativnim postavkama gospodarskog pristupa bit će više riječi infra, u poglavlju 5. Međutim, za potrebe prethodne rasprave važno je naglasiti kako se i gospodarski pristup tumačenju poreznopravnih normi, kao i srodne doktrine poznate $\mathrm{u}$ državama angloameričkog pravnog kruga, najčešće nastale kao odgovor na različite zloporabe poreznih obveznika, mogu uzeti u prilog teze o posebnosti poreznog prava. Drugim riječima, postojanje metode tumačenja poreznih propisa sukladno "gospodarskoj stvarnosti", slabo poznate u drugim pravnim područjima, može navesti na zaključak kako je porezno pravo doista u bitnome "drukčije" i kako njegova primjena u znatnoj mjeri odstupa od uobičajenih metodoloških obrazaca (vidi supra, poglavlje 2.1.). ${ }^{68}$

Ipak, suvremena doktrina na uvjerljiv način odbacuje tezu o posebnosti poreznog prava kad je posrijedi njegova primjena i tumačenje. Ukratko, koliko god specifične bile temeljne imovinskopravne posljedice nametanja i ubiranja poreza, to ne znači da su norme poreznog prava po svojoj prirodi drukčije od drugih normi unutar pravnog sustava. ${ }^{69}$ Uostalom, kako primjećuje Popović, "u krajnjoj liniji, za svaku društvenu oblast koja se uređuje zakonom moglo bi se reći da je "posebna'”. ${ }^{70}$ Stoga i u primjeni poreznih propisa valja polaziti od općeg okvira tumačenja pravnih normi, odnosno metoda izloženih supra (poglavlje 2.). Iz kuta kontinentalnoeuropske poreznopravne znanosti, posebno u djelima njemačkih pisaca, ovaj se zaključak čini samorazumljivim. ${ }^{71}$ Isti se stav može

65 Vidi Bydlinski, op. cit. u bilj. 4, str. 21; Krever i Van Brederode, op. cit. u bilj. 6, str. 8.

66 Vidi Tipke i Lang, op. cit. u bilj. 4, str. 139 - 140.

67 Heber i Sternberg, op. cit. u bilj. 23, str. 171 - 172; Koenig, op. cit. u bilj. 42, § 4 para. $96-97$.

68 O korištenju gospodarskog pristupa u drugim pravnim područjima, posebno u trgovačkom pravu, vidi Gassner, op. cit. u bilj. 23, str. 121 - 122.

69 Menéndez, op. cit. u bilj. 59, str. 321.

70 Popović, op. cit. u bilj. 19, str. 54.

71 Za možda i najuvjerljiviju formulaciju ovoga vidi Gassner, op. cit. u bilj. 23, str. 115 116. Njemački komentatori u prikazima tumačenja poreznog prava, koje smještaju $\mathrm{u}$ kontekst šire rasprave o načelu zakonitosti, gotovo beziznimno polaze od Von 
označiti prevladavajućim i u angloameričkoj doktrini, iako njezina ovisnost o hirovitom razvoju sudskih precedenata uvelike otežava sistematičnost prikaza primjene i tumačenja poreznog prava. $^{72}$

Uostalom, i institucionalni aspekti primjene poreznih normi upućuju na potrebu za odbacivanjem teze o poreznom ekscepcionalizmu. Naime, u svakoj državi tumačenje poreznih propisa uvelike je oblikovano općim postavkama pravnog stila i pristupa rasuđivanju koji slijede nadležni, ne nužno i specijalizirani, sudovi. ${ }^{73}$ Stoga je i prirodno očekivanje da sudska praksa teži uniformnom modelu pravnog tumačenja, pritom uzimajući u obzir specifične potrebe pojedinih pravnih područja. ${ }^{74}$

\section{OCRTAVANJE OKVIRA ZA TUMAČENJE POREZNIH PROPISA}

U prethodnom dijelu rada izložena teza kako tumačenje poreznih propisa nema "osobitu" narav u odnosu na pravno tumačenje ne predstavlja ujedno i negaciju određenih specifičnosti poreznopravnog odnosa. Naprotiv, upravo je poznavanje tih posebnih obilježja često pretpostavka pravilne primjene općih, tradicionalnih metoda tumačenja. Drugim riječima, opći okvir tumačenja pravnih odredaba valja tek dopuniti određenim metodološkim posebnostima, većina kojih izvire iz saznanja o cjelokupnom poreznom sustavu te ciljevima poreznih normi. ${ }^{75}$

Polazeći od navedenoga, u ovom se dijelu rada raščlanjuju glavne uporišne točke tumačenja poreznih propisa, o kojima njihovi primjenjivači moraju voditi

Savignyjevih četiriju kanona, prilagođenih poreznom kontekstu. Vidi, primjerice, Tipke i Lang, op. cit. u bilj. 4, str. 139 - 149; Koenig, op. cit. u bilj. 42, § 4 para. 86111; Klein, F., Abgabenordnung: Kommentar (12. izd.), C. H. Beck, München, 2014., § 4 para. $23-35$.

72 Vidi, primjerice, Freedman, op. cit. u bilj. 60, str. 63; Krever, R.; Mellor, P., Australia, u: Brederode, R. F.; Krever, R. (ur.), Legal Interpretation of Tax Law, Kluwer Law International, Alphen aan den Rijn, 2014., str. 28; Johnson, S. R., United States, u: Brederode, R. F.; Krever, R. (ur.), Legal Interpretation of Tax Law, Kluwer Law International, Alphen aan den Rijn, 2014., str. $344-345$.

73 Prema Thuronyi, op. cit. u bilj. 36, str. 133 - 135.

74 Usporedi Vanistendael, F., Legal framework for taxation, u: Thuronyi, V. (ur.), Tax Law Design and Drafting, International Monetary Fund, Washington D. C., 1996., str. 34. Za potvrdu navedenog u praksi američkih sudova vidi Johnson, op. cit. u bilj. 72, str. $344-345$.

75 Usporedi o metodološkim posebnostima pojedinih pravnih područja Bydlinski, op. cit. u bilj. 4, str. $20-21$. 
računa s ciljem oživotvorenja načela zakonitosti u pravnoj praksi. U nastavku ocrtani okvir tumačenja poreznih propisa, uz sistematsko izlaganje najvažnijih faza ili koraka, temelji se na prevladavajućem shvaćanju pravne dogmatike, napose pisaca njemačkog poreznopravnog kruga. S obzirom na njezinu iznimnu teorijsku i praktičnu važnost, analiza gospodarskog pristupa prikazana je u posebnom poglavlju.

\subsection{Utvrđivanje cilja poreznopravnih odredaba}

Ako se pođe od supra (poglavlje 2.) iznesene pretpostavke da se jedino ciljnim tumačenjem može otkriti pravo značenje pravne norme, ključni se korak u primjeni poreznih propisa zapravo svodi na zahtjev za prepoznavanjem ciljeva odredaba o poreznom obvezniku, poreznom objektu, poreznoj osnovici, poreznim povlaštenjima i drugim elementima koji zajednički tvore zakonski opis pretpostavki na kojima se zasniva oporezivanje (njem. Tatbestand).${ }^{76}$ Pritom je korisno imati u vidu opće ciljeve oporezivanja, koji se u teoriji dijele u dvije glavne skupine: fiskalni se cilj ostvaruje prikupljanjem javnih prihoda kojima se financira javna potrošnja, a nefiskalni ciljevi obuhvaćaju sve druge svrhe kojima može služiti nametanje određenog poreza (npr. ostvarenje ciljeva ekonomske, demografske, obrazovne ili koje druge javne politike). ${ }^{77}$ Slično tomu, Avi-Yonah, uz fiskalni cilj, razlikuje još dva temeljna cilja oporezivanja: redistribucijski (preraspodjela dohotka ostvarenog na tržištu) i regulatorni (usmjeravanje ponašanja privatnih subjekata). ${ }^{78}$

Međutim, prepoznavanje jednog ili više općih ciljeva kojima neki porez (npr. porez na dohodak, porez na dodanu vrijednost, porez na nekretnine) služi ne može imati odlučni utjecaj pri tumačenju poreznih propisa s obzirom na to da nužno vodi rezultatu nepovoljnom za poreznog obveznika. ${ }^{79}$ Stoga primjena teleološke metode u poreznom pravu zahtijeva analizu cilja ili funkcije pojedine odredbe relevantne za konkretno činjenično stanje. ${ }^{80}$ Tipke i Lang tako sve poreznopravne norme dijele u tri skupine: 1) norme koje primarno imaju fiskalni cilj (njem. Fiskalzwecknormen), 2) norme koje služe kakvom socijalnom

76 Detaljno o ovim elementima vidi Tipke i Lang, op. cit. u bilj. 4, str. 175 - 183.

77 Detaljnije o ciljevima oporezivanja vidi Mijatović, N., Teorijsko razmatranje nekih odrednica poreznog sustava, Hrvatska pravna revija, vol. 16, br. 2, 2016., str. $22-26$.

78 Avi-Yonah, R. S., The Three Goals of Taxation, Tax Law Review, vol. 60, br. 1, 2006. str. $22-25$.

79 Vidi Heber i Sternberg, op. cit. u bilj. 23, str. 169.

80 Usporedi i Tipke i Lang, op. cit. u bilj. 4, str. 141 - 142. 
ili regulatornom cilju (njem. Sozialzwecknormen) te 3) norme koje služe pojednostavnjenju poreznopravnog sustava (njem. Vereinfachungszwecknormen). ${ }^{81}$ Pritom ističu da tumačenje nikad ne smije biti vođeno isključivo fiskalnim ciljem stricto sensu, tj. pozivanjem na potrebu prikupljanja dovoljne količine novčanih sredstava za podmirenje javnih izdataka, s obzirom na to da čak i norme prve skupine moraju ostvarivati zahtjev da se ukupno porezno opterećenje između poreznih obveznika raspodijeli sukladno određenom standardu ili kriteriju, poput načela oporezivanja sukladno gospodarskoj snazi ili sposobnosti za plaćanje (njem. Leistungsfähigkeitsprinzip). ${ }^{82}$ Doista, čini se kako zanemarivanje navedenog nužno vodi ka tumačenju in dubio pro fisco, neprihvatljivom u okvirima pravne države. ${ }^{83}$

Dakako, jedna odredba može istodobno imati više ciljeva, što se može otkriti samo u širem normativnom kontekstu pojedinog poreznog oblika. Stoga ovdje vrijednu ulogu mogu imati, kako je istaknuto supra (poglavlje 2.), sistemska metoda $^{84}$, pravila pravne logike te, ako postoje, dokumenti koji upućuju na volju povijesnog zakonodavca. Primjerice, člankom 13. stavkom 1. hrvatskog Zakona o porezu na dobit ${ }^{85}$ propisano je: Ako se izmedu povezanih osoba u njihovim poslovnim odnosima ugovore takve cijene ili drugi uvjeti koji se razlikuju od cijena ili drugih uvjeta koji bi se ugovorili između nepovezanih osoba, tada se sva dobit u svoti u kojoj bi bila ostvarena, kad bi se radilo o odnosima između nepovezanih osoba, uključuje u poreznu osnovicu povezanih osoba. Cilj navedene odredbe nemoguće je razaznati bez uzimanja u obzir temeljnih normativnih postavki poreza na dobit u Republici Hrvatskoj te prepoznavanja sistemskih veza između ove odredbe i pravila o poreznom obvezniku i poreznoj osnovici. Takva će analiza rezultirati zaključkom kako je cilj citirane odredbe, kojom je u hrvatski sustav poreza na dobit ugrađeno tzv. načelo nepristrane transakcije (engl. arm's length principle), sprječavanje manipulacije transfernim cijenama između povezanih društava, odnosno postizanje jednakog tretmana, s aspekta poreza na dobit, ovih subjekata s tzv. nepovezanim osobama. Ujedno je moguće prepoznati da se zahtjev za jednakim poreznim

$81 \quad$ Ibid., str. $67-69$.

82 Ibid., str. 68 i 141 - 142. Općenito o važnosti kriterija gospodarske snage ili sposobnosti za plaćanje za ostvarenje načela pravednosti u području oporezivanja vidi Gadžo, S., Prilog istraživanju sadržaja načela pravednosti kao kriterija evaluacije normi međunarodnog poreznog prava, Pravni vjesnik, vol. 31, br. 2, str. 134 - 136.

83 Vidi Popović, op. cit. u bilj. 19, str. 54.

84 Stoga Englisch i upotrebljava termin "teleološko-sistemskog” tumačenja. Vidi Englisch, J., \& 5 Rechtsanwendung im Steuerrecht, u: Tipke, K.; Lang, J., Steuerrecht, Verlag Dr. Otto Schmidt, Köln, 2015., str. 200 - 203.

85 Narodne novine, br. 177/2004, 90/2005, 57/2006, 146/2008, 80/2010, 22/2012, 148/2013, 143/2014, 50/2016, 115/2016, 106/2018, 121/2019, 32/2020. 
tretmanom temelji na gore spomenutom konceptu raspodjele poreznog tereta prema gospodarskoj snazi, ugrađenog u članak 5l. stavak 1. Ustava RH. ${ }^{86}$

\subsection{Jezična analiza: određivanje granica tumačenja}

Važnost utvrđivanja cilja poreznih propisa i njihovih pojedinačnih odredaba ipak ne otvara prostor rezultatima tumačenja koji leže izvan granica na koje upućuje jezična metoda, tj. analiza teksta odredbe s gramatičkog, sintaktičkog i leksičkog aspekta. Supra naznačeno teorijsko razlikovanje "jezgre” nekog pojma i njegova "predvorja" relevantno je i kad je riječ o poreznim propisima. Tipke i Lang tako, priznajući da gotovo sve riječi sadržavaju određene varijante i nijanse sa semantičkog aspekta, odbacuju tezu o nepostojanju vanjskih granica mogućih značenja nekog pojma, s obzirom na to da bi se tada riječima moglo pridavati bilo koje značenje te bi razumijevanje bilo nemoguće. ${ }^{87} \mathrm{U}$ svakom slučaju, vrijedi ponoviti kako je jezično tumačenje to važnije što je uži (značenjski) opseg riječi upotrijebljenih u pravnim odredbama. ${ }^{88} \mathrm{Na}$ poštovanje vanjskih granica tumačenja, utvrđenih s pomoću jezične metode, upućuje i ustavno načelo zakonitosti, koje u području oporezivanja ima posebno značenje i izričaj (nullum tributum sine lege). ${ }^{89}$

Prekoračenje navedenih vanjskih granica, tj. mogućih značenja pojmova, znači da se primjenjivač pravne norme kreće u sferi “dopunjujućeg stvaranja prava” (njem. Rechtsforbildung). ${ }^{90} \mathrm{U}$ području oporezivanja ono izaziva prijepore, posebice u svjetlu načela zakonitosti i načela diobe vlasti. Prevladavajuće teorijsko stajalište da je i u primjeni poreznih normi moguće popunjavanje pravnih praznina pomoću analogije, čak i na štetu poreznog obveznika, potvrđuje novija praksa njemačkih sudova. ${ }^{91}$ Dakako, to je moguće pod veoma ograničenim uvjetima kad se pravnom normom, protumačenom u okviru granica jezične analize, ne bi mogao ostvariti njezin temeljni cilj u vezi s konkretnim činjeničnim stanjem. ${ }^{92}$ Tako se primjena analogije, kao i teleološke redukcije (vidi supra, poglavlje 2.),

86 Isti glasi: "Svatko je dužan sudjelovati u podmirenju javnih troškova, u skladu sa svojim gospodarskim mogućnostima."

87 Tipke i Lang, op. cit. u bilj. 4, str. 141.

88 Usporedi i Klein, op. cit., u bilj. 71, § 4 para. 27.

89 Vidi Vanistendael, op. cit. u bilj. 74, str. 35.

90 Vidi Bydlinski, op. cit. u bilj. 4, str. 69; Koenig, op. cit. u bilj. 42, § 4 para. 95; Englisch, op. cit. u bilj. 84, str. 199. Usporedi i Visković, op. cit. u bilj. 7, str. $262-263$.

91 Heber i Sternberg, op. cit. u bilj. 23, str. 173 - 175.

92 Vidi Bydlinski, op. cit. u bilj. 4, str. 74 - 75; Tipke i Lang, op. cit. u bilj. 4, str. 150. 
dopušta jedino ako tumačenje vodi rezultatu koji je apsurdan, protivan ekonomskoj logici ili se jasno protivi namjeri zakonodavca. ${ }^{93}$

\subsection{Posebno o tumačenju "transplantiranih" pojmova}

"Jezik poreznog prava" uvelike je udaljen od prirodnog ili općeg jezika. ${ }^{94}$ Naime, u poreznim propisima dominira uporaba pojmova koji se koriste $u$ drugim granama prava i imaju svoje značenje u okviru stručnog pravnog nazivlja. To je posljedica same prirode oporezivanja, u kojemu se nastanak porezne obveze u pravilu veže uz aktivnosti poreznih obveznika koje su već regulirane, klasificirane ili kvalificirane normama drugih pravnih grana, napose privatnog prava $u$ širem smislu. ${ }^{95}$ Primjerice, pojmovi "poslodavac", "posloprimac" i "plaća” ubrajaju se u temeljne pojmove radnog prava, koji se u identičnom obliku koriste prilikom uređivanja poreznog tretmana dohotka od nesamostalnog rada. ${ }^{96}$ Pitanje vrijednosti izvornog normativnog značenja takvih "posuđenih" ili "transplantiranih" pojmova kad se oni upotrebljavaju u poreznopravnom kontekstu i dalje ostaje predmetom žestokih doktrinarnih rasprava. ${ }^{97}$

Iako je navedeno pitanje važno u gotovo svim državama, pogotovo onima kontinentalnog pravnog kruga, opet je najdalje otišla njemačka dogmatika, inspirirana i nizom često oprečnih odluka Saveznog ustavnog suda (Bundesverfassungsgericht, dalje u tekstu: BVerFG). S jedne su strane autori koji smatraju da se takvim pojmovima i u poreznopravnom kontekstu mora pridavati značenje jednako onomu koje imaju u izvornom privatnopravnom području. Navedeni se stav opravdava i pozivanjem na načelo pravne sigurnosti te potrebom očuvanja jedinstva pravnog sustava (njem. Einheit der Rechtsordnung). ${ }^{98} \mathrm{U}$ ranijoj praksi BVerFG-a ova doktrina o "primatu" privatnog prava u primjeni poreznih

93 Heber i Sternberg, op. cit. u bilj. 23, str. 175; Koenig, op. cit. u bilj. 42, § 4 para. 112.

94 Općenito o odnosu prava i jezika vidi Vrban, D., Država i pravo, Golden marketing, Zagreb, 2003., str. 434 - 438. Usporedi i, u kontekstu poreznog prava, Englisch, op. cit. u bilj. 84, str. 199.

95 Vidi Tipke i Lang, op. cit. u bilj. 4, str. 6 - 7. Općenito o pojmu "privatnog prava" kako se koristi dalje u tekstu vidi Gavella, N., Privatno pravo, Narodne novine, Zagreb, 2019., str. 3 - 6 .

96 Vidi članak 21. Zakona o porezu na dohodak (Narodne novine, br. 115/2016, 106/2018, 121/2019, 32/2020; dalje u tekstu: ZPDoh).

97 Vidi Krever i Van Brederode, op. cit. u bilj. 6, str. 8 - 9; Heber i Sternberg, op. cit. u bilj. 23, str. $170-171$.

98 Heber i Sternberg, op. cit. u bilj. 23, str. 170; Tipke i Lang, op. cit. u bilj. 4, str. 148. 
propisa formulirana je na sljedeći način: kad se u poreznim propisima koriste privatnopravni pojmovi, pretpostavlja se da je i njihovo značenje jednako, osim ako ne postoje posebno opravdani razlozi za drukčiji zaključak. ${ }^{99}$

Na drugoj strani spektra nalaze se zastupnici teorije o potpunoj neovisnosti tumačenja poreznih propisa o značenjima utvrđenim u privatnom pravu, čak i kad je riječ o "posuđivanju" pojmova. U prilog se tomu stavu ističu supra izložene specifičnosti poreznog prava s teleološkog aspekta zbog čega nužno dolazi do "transformacije" značenja: u tom smislu privatnopravno značenje tvori samo jezgru pojma te je moguće i šire tumačenje u skladu s ciljevima oporezivanja. ${ }^{100}$ Ova argumentacijska linija u velikoj se mjeri isprepleće s doktrinom gospodarskog pristupa ili prevage ekonomskog sadržaja nad pravnom formom, o čemu će više riječi biti infra (poglavlje 5.). U svakom slučaju, počevši od 1991. godine BVerFG mijenja svoj stav, obrazlažući da se odredbe poreznih propisa uvijek moraju tumačiti neovisno o privatnopravnim značenjima, čak i u slučaju transplantiranih pojmova, s obzirom na to da unutar cjelokupnog pravnog sustava privatno pravo nema primat nad poreznim pravom, a ciljevi navedenih pravnih grana posve su različiti. ${ }^{101}$

Polazeći od gore izloženog obrazloženja važnosti ciljnog tumačenja poreznih propisa, kao i uloge jezičnog tumačenja, čini se da je ipak moguće doći do uravnoteženog pogleda na mjesto privatnopravnih pojmova u poreznom kontekstu. Naime, u pojedinim se slučajevima zakonski elementi poreza izričito vežu za privatnopravnu kvalifikaciju činjeničnog stanja te bi odstupanje u određenju sadržaja predmetnih pojmova ili instituta bilo u suprotnosti s ciljem porezne norme. ${ }^{102}$ Primjerice, sadržaj pojmova korištenih prilikom normativnog uređenja poreza na nasljedstva i darove (npr. pojam nasljednika i daroprimatelja) mora se podudarati s njihovim privatnopravnim značenjem jer to nalažu temeljni ciljevi ovog poreznog oblika. ${ }^{103}$ Također, u nekim će slučajevima zakonodavac posegnuti za izričitim upućivanjem na potrebu usvajanja privatnopravnih značenja. Tako članak 21. ZPDoh-a upućuje da su za utvrđivanje pojma primitaka od nesamostalnog rada relevantni radnopravni propisi, a čl. 9. ZPDob-a upućuje na stečajne propise prilikom utvrđenja poreznog tretmana vrijednosnih usklađenja i otpisa potraživanja.

99 Vidi detaljnije Osterloh, L., Tax Law and Private Law, u: Amatucci, A. (ur.), International Tax Law, Kluwer Law International, Alphen aan den Rijn, 2012., str. 90 - 92.

100 Tipke i Lang, op. cit. u bilj. 4, str. 147 - 148.

101 Heber i Sternberg, op. cit. u bilj. 23, str. 171.

${ }_{102}$ Usporedi Tipke i Lang, op. cit. u bilj. 4, str. 7.

${ }_{103}$ Usporedi i argumentaciju izloženu infra, poglavlje 5.2. 
S druge strane, u značajnom broju slučajeva, osobito kod propisa koji uređuju najvažnije porezne oblike (porez na dohodak, porez na dobit, PDV, imovinski porezi), uporaba privatnopravnih pojmova ne znači i vezivanje za njihov izvorni značenjski opseg. Ovdje se ističu primjeri pojmova kojima se u poreznim propisima opisuju ekonomske aktivnosti fizičkih i pravnih osoba koje dovode do nastanka porezne obveze - poput pojmova "zakup", "otuđenje", "gospodarska djelatnost" i dr. - a čija privatnopravna značenja primjenjivač porezne norme mora uzeti u obzir, ali ne nužno i prihvatiti. ${ }^{104}$ Naime, u navedenim je slučajevima potrebno imati u vidu specifične ciljeve oporezivanja i mjesto norme unutar cjelokupnog poreznopravnog sustava. ${ }^{105}$ Nerijetko će upravo gore navedeni cilj raspodjele poreznog tereta sukladno gospodarskoj snazi nalagati drukčije, šire shvaćanje nekog pojma u poreznopravnom kontekstu.

Dakako, u praktičnom se smislu opisane nedoumice uvelike smanjuju kad porezni propisi sadržavaju iscrpne normativne definicije iz kojih je jasno vidljiv otklon u odnosu na privatnopravna ili druga moguća značenja upotrijebljenih pojmova.

\section{POSEBNO O "GOSPODARSKOM PRISTUPU" ILI "GOSPODARSKOM TUMAČENJU"}

U radu je već na više mjesta naznačeno kako se najizrazitija posebnost tumačenja poreznih propisa iskazuje u doktrini tzv. gospodarskog pristupa, koju se katkad naziva i "gospodarskim tumačenjem". ${ }^{106}$ Idejni je tvorac te doktrine njemački porezni stručnjak Enno Becker ${ }^{107}$, pod čijim utjecajem 1919. godine biva ugrađena u zakonodavstvo Weimarske Republike. ${ }^{108}$ Iako sve od 1977. godine i donošenja $\mathrm{AO}$-a primjena gospodarskog pristupa nije izričito propisana njemačkim zakonima, i dalje zauzima utjecajno mjesto u tamošnjoj dogmatici

104 Vidi Gassner, op. cit. u bilj. 23, str. 136; Englisch, op. cit. u bilj. 84, str. 203 - 204.

105 Tipke i Lang, op. cit. u bilj. 4, str. 7. Usporedi Koenig, op. cit. u bilj. 42, § 4 para. 109 - 110; Klein, op. cit. u bilj. 71, § 4 para. 35.

106 Za prikaze u domaćoj pravnoj književnosti vidi Lončarić-Horvat, op. cit. u bilj. 5, str. 540 - 544; Šinković, op. cit. u bilj. 27, str. 201 - 216.

107 O liku i djelu ovog velikana poreznopravne misli vidi Pürner, S., Dr. h. c. Enno Becker (1869-1940), Nova pravna revija, br. 2, 2014., str. 68 - 74.

108 O društvenom i povijesnom kontekstu uvođenja doktrine gospodarskog pristupa u njemačko zakonodavstvo vidi Gassner, op. cit. u bilj. 23, str. 17 - 20. 
i sudskoj praksi. ${ }^{109}$ Štoviše, pod očitim utjecajem ranijih njemačkih rješenja, u nizu država kontinentalnog pravnog kruga ta je metodološka smjernica za primjenu poreznih normi i danas izričito propisana, najčešće u sistemskom zakonu koji uređuje područje poreza i drugih javnih davanja. ${ }^{110}$ Tako je u članku 21. austrijskog Saveznog zakona o javnim davanjima (Bundesabgabenordnung, dalje u tekstu: $\mathrm{BAO}$ ) propisano da je za ocjenjivanje poreznopravnih pitanja, sukladno gospodarskom pristupu, mjerodavan stvarni ekonomski sadržaj (njem. wahre wirtschaftliche Gehalt), a ne vanjski oblik činjeničnog stanja (njem. äußere Erscheinungsform des Sachverhaltes). ${ }^{111}$ U slučaju Hrvatske mjerodavan je članak 1l. stavak 1. OPZ-a, koji propisuje: Porezne činjenice utvrduju se prema njihovoj gospodarskoj biti.

U literaturi se često ističe da je doktrina gospodarskog pristupa u gotovo istovjetnom obliku razvijena kroz sudsku praksu i u nekim državama angloameričkog pravnog kruga pod imenom "prevage sadržaja nad formom" (engl. substance over form). ${ }^{112}$ Međutim, detaljnija će analiza, posebno jurisprudencije Vrhovnog suda SAD-a, uputiti na veoma značajne konceptualne razlike. Ukratko, dok gospodarski pristup u kontinentalnim pravnim porecima ima status općeg načela koje dopunjuje metodološki okvir primjene i tumačenja poreznih propisa, prevaga sadržaja nad formom u angloameričkom pravu nastala je kao posljedica sudskog aktivizma u sprječavanju pojedinih oblika porezne evazije. ${ }^{113}$ S obzirom na to da, barem iz teorijskog kuta, tumačenje poreznih propisa i sprječavanje porezne evazije valja tretirati kao zasebna pitanja ${ }^{114}$, u nastavku se ovog poglavlja naglasak stavlja upravo na "kontinentalni model", tj. na analizu značenja doktrine gospodarskog pristupa u državama kontinentalnog prava. Dakako, na praktičnoj su razini razlike manje jer se i u potonjoj skupini zemalja

109 Vidi Thuronyi, op. cit. u bilj. 36, str. 194 - 195; Klein, op. cit., u bilj. 71, § 4 para. $23-24$.

110 Takva zakonska rješenja nalazimo, primjerice, u Hrvatskoj, Austriji, Mađarskoj, Srbiji, Sloveniji, Češkoj, Slovačkoj i Turskoj. Detaljnije vidi pojedina nacionalna izvješća u Lang, M. et al. (ur.), GAARs - A Key Element of Tax Systems in the Post-BEPS World, IBFD, Amsterdam, 2016.

111 Za detaljan komentar ovog članka vidi Stoll, G., Bundesabgabenordnung: Kommentar, Verlag Orac, Wien, 1994., str. 216 - 239.

112 Vidi npr. Zimmer, F., General Report, u: Form and Substance in Tax Law, Cahiers de droit fiscal international, vol. 87a, Kluwer, 2002., str. 25 - 28; Thuronyi, op. cit. u bilj. 36, str. $170-184$.

113 Za pregled relevantne sudske prakse američkih sudova vidi npr. Thuronyi, op. cit. u bilj. 36, str. $160-171$.

114 Usporedi Klein, op. cit. u bilj. 71, § 4 para. 24; Englisch, op. cit. u bilj. 84, str. 214 -215 . 
porezna tijela i sudovi pozivaju na doktrinu gospodarskog pristupa najčešće u slučajevima "agresivnog" poreznog planiranja.

Za države u čijem zakonodavstvu nalazimo pravilo usporedivo onom iz članka 21. austrijskog BAO-a ili članka 11. stavka 1. OPZ-a ključno je odrediti njegove pravne učinke. Drugim riječima, potrebno je ustanoviti mjesto i značenje gospodarskog pristupa unutar općeg metodološkog okvira primjene poreznih normi. S obzirom na to da o ovom pitanju u pravnoj književnosti i sudskoj praksi izostaje konsenzus, u nastavku se raščlanjuju najvažnije interpretacije. Prethodno vrijedi nadodati da u hrvatskom i usporednom zakonodavstvu nalazimo i niz specifičnih pravila koja se smatraju odrazom doktrine gospodarskog pristupa poput pravila o oporezivanju dohotka stečenog bez pravne osnove ili pravila o priračunavanju gospodarskih dobara, čija analiza prelazi granice ovog rada. ${ }^{115}$

\subsection{Gospodarski pristup kao "opći korektiv" u odnosu na privatno pravo}

Ugrađivanje gospodarskog pristupa u članak 4. njemačkog RAO-a 1919. godine može se u najvećoj mjeri pripisati težnji da se u tumačenju poreznih propisa dokine dotadašnji primat građanskog prava, odnosno praksa rigidnog prihvaćanja privatnopravnih značenja i u poreznom kontekstu. ${ }^{116}$ Sam je Becker gospodarski pristup opisao kao "opći korektiv" (njem. allgemeines Korrektiv) s obzirom na to da zahtijeva transformaciju ili pretvorbu privatnopravnih pojmova korištenih u poreznim odredbama: oni služe tek kao pomoćno sredstvo pri opisu ekonomskih transakcija ili stanja na čiji je sadržaj oporezivanje usmjereno. ${ }^{117}$ U njemačkoj teoriji i praksi međuratnog razdoblja prihvaćen je ovaj pogled koji u svojoj ekstremnoj varijanti vodi zaključku o potpunoj nevažnosti privatnopravnih kvalifikacija za primjenu poreznih propisa. ${ }^{118}$

Kasnija je pravna književnost, međutim, odbacila takvu interpretaciju uloge gospodarskog pristupa. To je ponajprije posljedica brige za očuvanje minimuma pravne sigurnosti poreznih obveznika, koji bi veoma teško mogli procijeniti poreznopravne posljedice vlastitih pravnih poslova kad bi porezna tijela i sudovi pri utvrđivanju porezne obveze polazili od jednog metodološki posebnog

115 Za pregled vidi Englisch, op. cit. u bilj. 84, str. 210 - 222; Lončarić-Horvat, op. cit. u bilj. 5, str. 540 - 544 .

116 Vidi Gassner, op. cit. u bilj. 23, str. 18.

117 Prema Tipke i Lang, op. cit. u bilj. 4, str. 147 - 148.

118 Vidi Gassner, op. cit. u bilj. 23, str. 20 i 131 - 132. 
pristupa usmjerenog isključivo na "ekonomsku stvarnost". ${ }^{119}$ U svakom slučaju, viđenje gospodarskog pristupa kao "općeg korektiva” teško je pomiriti s općim postavkama primjene i tumačenja i pravnih normi (vidi supra, poglavlje 2.1.), s obzirom na to da ono primjenjivača/tumača barem implicitno udaljuje od teksta porezne odredbe, kao i ispitivanja njezina cilja, stavljajući naglasak na specifičnu ekonomsku analizu relevantnih činjenica. ${ }^{120}$ Tipke i Lang dodaju kako se gospodarski pristup u praksi zapravo nikad i nije dosljedno primjenjivao u varijanti "općeg korektiva" privatnopravnih koncepata, na što upućuje i primjena načela zasebnog subjekta (njem. Trennungsprinzip) pri oporezivanju dobiti trgovačkih društava i drugih pravnih osoba, umjesto da se ostvareni prihodi i rashodi izravno pripisuju članovima društva. ${ }^{121}$

\subsection{Gospodarski pristup kao element ciljnog tumačenja poreznih propisa}

U literaturi njemačkog poreznopravnog kruga danas prevladava mišljenje kako je gospodarski pristup usko povezan s metodom ciljnog tumačenja poreznih propisa. Tako Tipke i Lang navode kako gospodarski pristup "sadržava zahtjev za ciljnim tumačenjem". ${ }^{12}$ Prema Englischu to je "dio sistemsko-teleološkog tumačenja poreznog prava, s obzirom na to da služi jednakom opterećenju ekonomski usporedivih aktivnosti i stanja". ${ }^{123}$ Koenig ističe kako je zapravo riječ o "posebnoj teleološkoj metodi tumačenja"124, dok Gassner u gospodarskom pristupu prije svega vidi "element ciljnog tumačenja”. ${ }^{125}$

Bez obzira na suptilne razlike između citiranih i drugih definicija, svi se autori slažu oko sljedećih bitnih točaka:

(i) gospodarski pristup, bez obzira na to je li izričito propisan zakonom ili je plod razvoja sudske prakse, ne podupire tezu o "poreznom ekscepcionalizmu” (vidi supra, poglavlje 2.2.); naprotiv, riječ je o metodološkoj

119 Detaljno vidi ibid., str. $132-137$.

120 Usporedi Gassner, op. cit. u bilj. 23, str. 105. Gassner upozorava kako ni Enno Becker u članku 4. RAO-a nije vidio posebnost poreznog prava, već je njegova namjera bila kroz gospodarski pristup naglasiti da se i u ovom području primjenjuju opća načela primjene pravnih normi. Vidi ibid., str. 19.

121 Tipke i Lang, op. cit. u bilj. 4, str. 148.

122 Loc. cit.

123 Englisch, op. cit. u bilj. 84, str. 203.

124 Koenig, op. cit. u bilj. 42, § 4 para. 107.

125 Gassner, op. cit. u bilj. 23, str. 122. 
posebnosti primjene poreznih propisa, koju valja uklopiti u opći okvir primjene i tumačenja pravnih normi;

(ii) pri tumačenju poreznih propisa metoda ciljnog tumačenja ima ključno mjesto (vidi supra, poglavlje 2.3.1.); u tom smislu gospodarski pristup predstavlja samo izraz i odraz cilja većine poreznih normi - prikupljanja javnih prihoda od fizičkih i pravnih osoba podvrgnutih suverenoj vlasti države u povodu određenih ekonomskih aktivnosti (npr. promet na tržištu, ostvarenje dohotka i dr.) kao pokazatelja ukupne gospodarske snage poreznih obveznika; ${ }^{126}$ ovaj je cilj povezan i s ustavnim načelom jednakosti, koje nalaže da aktivnosti ili situacije koje su u gospodarskom smislu jednake proizvedu i jednake poreznopravne posljedice, tj. imaju jednak poreznopravni tretman, što bi u konačnici trebalo osigurati ravnomjerno porezno opterećenje poreznih obveznika uzimajući u obzir njihovu gospodarsku snagu ${ }^{127}$;

(iii) gospodarski pristup postavlja zahtjev da se pri ispitivanju značenja pojmova korištenih u poreznim odredbama, uključujući i pojmove posuđene iz privatnog prava, posebna pozornost obrati na njihov gospodarski sadržaj i smisao, pod uvjetom da je cilj norme u pitanju zahvaćanje jednog dijela gospodarske snage poreznog obveznika; u tom smislu slijepo prihvaćanje privatnopravnih kvalifikacija, bez ispitivanja cilja porezne norme, nije dopušteno.

Drugim riječima, prema prevladavajućem shvaćanju pravne književnosti doktrina gospodarskog pristupa ponajprije služi kao metodološka smjernica pri utvrđivanju uloge privatnopravnih pojmova rabljenih u poreznopravnom kontekstu. ${ }^{128}$ Pritom pridjevak "gospodarski" zapravo predstavlja afirmaciju posebne uloge ciljne metode za tumačenje poreznih propisa. Kako obrazlaže Potacs, izričito određenje gospodarskog pristupa daje posebnu težinu ciljnoj metodi prilikom vaganja između različitih metoda tumačenja. ${ }^{129}$ Slično tomu, Gassner ističe kako propisivanje gospodarskog pristupa otkriva temeljni stav ili

126 Za prikaz ciljeva poreznih normi vidi supra, poglavlje 4.1.

127 O ovomu detaljnije vidi Potacs, M., "Wirtschaftliche Betrachtungsweise" als steuerrechtliches Interpretationsprinzip, u: Urnik, S.; Fritz-Schmied, G.; Kanduth-Kristen, S. (ur.), Steuerwissenschaften und betriebliches Rechnungswesen. Strukturen-Prinzipien-Neuerungen. Festschrift für Herbert Kofler, Linde, Wien, 2009., str. 157 - 158. Usporedi i Englisch, op. cit. u bilj. 84, str. 203.

128 Usporedi Tipke i Lang, op. cit. u bilj. 4, str. 148 - 149.

129 Potacs, op. cit. u bilj. 127, str. 153. 
filozofiju zakonodavca u području oporezivanja, upućujući na potrebu uzimanja u obzir gospodarskog smisla i cilja poreznih odredaba. ${ }^{130}$

Za usporedbu, Arbutina i Rogić Lugarić na sljedeći način analiziraju značenje načela gospodarskog pristupa, utjelovljenog u članku 11. stavku 1. OPZ-a: oporezivanje je u pravilu usmjereno na novostvorenu vrijednost, kao porezno dobro; stoga upravo ostvarenje novostvorene vrijednosti predstavlja gospodarsku bit koja služi kao kriterij za utvrđivanje postojanja porezne činjenice. ${ }^{131}$ "Iz toga proizlazi da prilikom oporezivanja treba voditi računa samo o ostvarenju gospodarske biti, pri čemu je formalno-pravni aspekt manje važan". ${ }^{132}$ Odraz takvog pristupa jest i posebno pravilo o oporezivanju poreznog dobra ostvarenog protupravno, primjerice, počinjenjem kaznenog djela (čl. 11. st. 2. OPZ-a). ${ }^{133}$ Opisano stajalište hrvatske dogmatike lako je pomiriti s prethodno iznesenim mišljenjima pisaca njemačkog poreznopravnog kruga s obzirom na to da je također teleološki orijentirano. Naime, Arbutina i Rogić Lugarić u svojoj analizi polaze od pretpostavljenog cilja kojemu zakonodavac teži, ili bi barem trebao težiti, u području oporezivanja, a to je nametanje poreza na novostvorenu vrijednost.

U svakom slučaju, prilikom primjene poreznih normi jasno se razaznaju i granice gospodarskog pristupa. Prvo, gospodarski pristup ne daje dozvolu primjenjivaču norme za prekoračenje vanjskih granica tumačenja na koje upućuje jezična analiza, kako je već istaknuto supra (poglavlje 2.3.2.). ${ }^{134}$ Drugo, i značajnije, primjena gospodarskog pristupa ovisi o tehnici zakonskog opisa oporezivog događaja i drugih elemenata poreza (njem. Technik der Tatbestandsbildung). ${ }^{135}$ Naime, nema mjesta primjeni gospodarskog pristupa ako je zakonodavac pri opisu zakonskih elemenata poreza polazio od (formalno)pravne perspektive, tj. ako je situacija navedena $u$ hipotezi porezne norme izričito vezana uz činjenice i stanja koja se klasificiraju i utvrđuju prema pravilima koje druge pravne grane, napose privatnog prava.

Kako ističe Gassner, to je ponajprije slučaj kod pristojbi te različitih "poreza na pravni promet" (njem. Rechtsverkehrsteuer) kao što je porez na nasljedstva i darove ili porez na promet nekretnina. ${ }^{136}$ Moguće je uzeti za primjer i tzv.

${ }^{130}$ Gassner, op. cit. u bilj. 23, str. 118 - 119.

131 Arbutina i Rogić Lugarić, op. cit. u bilj. 25, str. 8 - 9.

132 Ibid., str. 9.

133 Loc. cit.

134 Usporedi i Klein, op. cit. u bilj. 71, § 4 para. 34.

135 Gassner, W., Austria, u: Form and Substance in Tax Law, Cahiers de droit fiscal international, vol. 87a, Kluwer, 2002., str. 122.

136 Loc. cit. 
upravne pristojbe na stjecanje rabljenih motornih vozila u Republici Hrvatskoj, zapravo posebnog poreza na promet. ${ }^{137}$ Nastanak obveze plaćanja tog javnog davanja vezan je isključivo uz formalnopravnu pretpostavku prijenosa vlasništva nad rabljenim motornim vozilom, odnosno registraciju motornog vozila na ime stjecatelja. ${ }^{138} \mathrm{U}$ takvom slučaju nema mjesta za primjenom gospodarskog pristupa, odnosno utvrđivanjem ekonomskog smisla ili cilja zakonske odredbe s obzirom na to da se zakonodavac jasno i svjesno opredijelio za usko vezivanje poreznopravnih učinaka za formalnopravnu kvalifikaciju relevantnog činjeničnog stanja.

S druge strane, kad je riječ o važnijim i izdašnijim porezima poput poreza na dohodak, poreza na dobit ili PDV-a, u mjerodavnim se zakonskim odredbama pokušava opisati određena gospodarska aktivnost podložna oporezivanju, neovisno o formalnopravnim pretpostavkama ili kvalifikacijama. ${ }^{139}$ Ovdje gospodarski pristup dolazi do svojeg punog izražaja s obzirom na to da će pojmovi upotrijebljeni u zakonskim odredbama nerijetko biti istovjetni privatnopravnim pojmovima, ali se, uzimajući u obzir cilj porezne norme, njihov sadržaj ne mora nužno poklapati. Primjerice, pojam "najamnine" ili "zakupnine" kao oporezivog primitka opisanog u članku 56. ZPDoh-a nije vezan uz privatnopravnu kvalifikaciju nekog pravnog odnosa kao najma ili zakupa. Naprotiv, gospodarski pristup nalaže da se utvrdi je li u konkretnom slučaju došlo do ostvarenja primitka na temelju takvog odnosa između poreznog obveznika i druge osobe, koji se u gospodarskom smislu može označiti najmom ili zakupom, tj. davanjem određenog imovinskog predmeta na uporabu ili korištenje uz naknadu. Dakako, u najvećem broju slučajeva privatnopravno određenje nekog odnosa kao najma ili zakupa ispravno će reflektirati navedenu gospodarsku bit. ${ }^{140}$

$\mathrm{Na}$ tragu navedenoga Potacs zaključuje kako je za primjenu doktrine gospodarskog pristupa nužna ex ante analiza, čija je svrha utvrditi treba li u konkretnom slučaju uopće posegnuti za gospodarskim pristupom kao elementom ciljnog tumačenja. ${ }^{141}$ Drugim riječima, primjenjivač porezne norme mora prethodno utvrditi vezuje li se zakonski opis oporezivog događaja za "gospodarsku stvarnost" ili za formalnopravne pretpostavke. U potonjem se slučaju može

137 Zanimljivo, sve do 1. siječnja 2018. za ovo se javno davanje koristio, po stajalištu autora ispravniji, naziv "posebni porez na stjecanje rabljenih motornih vozila".

138 Vidi članak 26. Zakona o posebnom porezu na motorna vozila (Narodne novine, br. 15/2013, 108/2013, 115/2016, 127/2017 i 121/2019).

139 Gassner, op. cit. u bilj. 135, str. $122-123$.

${ }^{140} \mathrm{O}$ tomu da privatnopravne kvalifikacije najčešće i ne stoje u opreci s gospodarskim sadržajem vidi infra, poglavlje 5.3., tekst uz bilješke 159 i 160.

141 Potacs, op. cit. u bilj. 127, str. 153. 
pretpostaviti kako je primjena gospodarskog pristupa suprotna volji zakonodavca te je stoga i isključena. ${ }^{142}$

\subsection{Gospodarski pristup kao metoda ocjenjivanja činjeničnog stanja}

Konačno, u literaturi se nalazi i stajalište kako gospodarski pristup zapravo uopće nije povezan s tumačenjem poreznih odredaba, već igra ulogu isključivo tijekom utvrđivanja i/ili ocjenjivanja činjeničnog stanja kao posebne faze primjene (porezno)pravne norme. Ovo stajalište (njem. Beurteilungslehre) ima posebno istaknuto mjesto u austrijskoj doktrini, što se može pripisati i specifičnom izričaju članka 21. BAO-a (vidi supra). ${ }^{143} \mathrm{Na}$ isto može upućivati i jezična analiza odredbe članka 11. stavka 1. OPZ-a, u kojem se izrijekom spominje "utvrđivanje poreznih činjenica".

U ustaljenoj praksi austrijskog Vrhovnog upravnog suda (Verwaltungsgerichtshof, dalje u tekstu: $\mathrm{VwGH}_{w}$ ) tako je određeno da se gospodarski pristup ne primjenjuje prilikom tumačenja poreznih odredaba, već služi za utvrđivanje i ocjenjivanje činjeničnog stanja. ${ }^{144}$ Preciznije, pravilo o gospodarskom pristupu, poput onog iz članka 21. BAO-a, postavlja zahtjev da primjenjivač porezne norme utvrdi i ocijeni životno, zbiljsko činjenično stanje (njem. Lebenssachverhalt) iz gospodarske (ekonomske) perspektive. Drugim riječima, potrebno je utvrditi ekonomski sadržaj činjenica slučaja, neovisno o formalnopravnom obliku transakcije ili aktivnosti u pitanju. ${ }^{145}$ Ova faza primjene norme prethodi supsumciji, odnosno podvođenju konkretnih činjenica slučaja pod apstraktno izraženu hipotezu pravne norme. ${ }^{146}$ Sukladno tomu, postupak utvrđivanja i ocjenjivanja činjeničnog stanja odvojen je i neovisan o tumačenju pravnih odredaba. ${ }^{147}$

Opisano je stajalište, međutim, predmetom žestokih kritika u suvremenoj literaturi te se, bar u obliku formuliranom u praksi VwGH-a, može ocijeniti i napuštenim, u prvom redu u svjetlu teorijskih osnova metodologije primjene

142 Loc. cit.

143 Gassner povijesni korijen navedenog stajališta nalazi u odredbama njemačkog Zakona o usklađivanju poreza (Steueranpassungsgesetz) iz 1934., koji se u doba nacističke vladavine primjenjivao i na području današnje Austrije. Vidi Gassner, op. cit. u bilj. 23, str. 22.

144 Prema Potacs, op. cit. u bilj. 127, str. 146; Gassner, op. cit. u bilj. 23, str. 25 - 26.

145 Gassner, op. cit. u bilj. 23, str. 24.

146 Detaljnije o postupku supsumcije vidi Vrban, op. cit. u bilj. 94, str. 445.

147 Gassner, op. cit. u bilj. 23, str. 24. Usporedi i Zimmer, op. cit. u bilj. 112, str. 28. 
prava. ${ }^{148}$ Naime, postupak ocjenjivanja konkretnog činjeničnog stanja nemoguće je odvojiti od apstraktnog (normativnog) činjeničnog stanja opisanog u zakonu $^{149} \mathrm{~s}$ obzirom na to da primjenjivač norme uvijek pristupa utvrđivanju činjenica u svjetlu apstraktnog sadržaja zakonskih odredaba. ${ }^{150}$ Drugim riječima, hipoteze pravnih normi glavni su kriterij za ocjenjivanje odlučnih činjenica, što se obavlja neposrednim zapažanjem ili različitim dokaznim radnjama. ${ }^{151}$ Ako se opet uzme u obzir u uvodu izloženo Viskovićevo razlikovanje pet osnovnih faza primjene pravnih normi, četvrta faza obuhvaća i utvrđivanje konkretnih činjenica i njihovu kvalifikaciju normativnim značenjima iz pravnih odredaba. ${ }^{152}$ Stoga Visković upozorava da pravno tumačenje ima važnost i tijekom ove faze s obzirom na to da je bez tumačenja nemoguća kvalifikacija stvarnih okolnosti kao "pravnih činjenica". ${ }^{153}$ Slično tomu, Gassner upozorava na dijalektički odnos između utvrđivanja činjeničnog stanja i tumačenja: pogled primjenjivača pravne norme nužno skače s konkretnih činjenica na apstraktno izražene dijelove pravnih odredaba i natrag, vodeći k interpretaciji odredaba u svjetlu činjenica slučaja, kao i ocjenjivanju činjenica slučaja u svjetlu zakona. ${ }^{154} \mathrm{U}$ tome i jest bit složene operacije supsumcije kao približavanja stvarnog i normativnog stanja. ${ }^{155}$

$\mathrm{Na}$ istom tragu, Potacs naglašava kako postupak utvrđivanja i ocjenjivanja činjeničnog stanja nužno pretpostavlja neki vanjski element, tj. kriterij procjene. Kad je riječ o primjeni pravnih normi, to je nužno zakonski opis apstraktnih činjenica te stoga tumačenje pravnih odredaba igra ulogu i prilikom utvrđivanja i kvalifikacije činjenica slučaja. ${ }^{156}$ Zato nema smisla shvaćanje prema kojem doktrina gospodarskog pristupa nalaže nekakvo "ekonomsko" utvrđivanje ili ocjenjivanje činjenica slučaja, odnosno procjenu "ekonomskog sadržaja” životne situacije, pri čemu se ne uzima u obzir normativno značenje dijelova pravne

148 Vidi Potacs, op. cit. u bilj. 127, str. 146.

149 O razlici između stvarnog i normativnog činjeničnog stanja vidi Vrban, op. cit. u bilj. 94 , str. $444-445$.

150 Vidi Gassner, op. cit. u bilj. 23, str. 36 - 37.

151 Usporedi Visković, op. cit. u bilj. 7, str. 265.

152 Visković, op. cit. u bilj. 1, str. 369. Za pojmovno određenje pravnih činjenica vidi Klarić, P.; Vedriš, M., Gradansko pravo: Opći dio, stvarno pravo, obvezno i nasljedno pravo, Narodne novine, Zagreb, 2014., str. 25.

153 Ibid., str. 373.

154 Gassner, op. cit. u bilj. 23, str. 147.

155 Vidi Tipke i Lang, op. cit. u bilj. 4, str. 137; Koenig, op. cit. u bilj. 42, § 4 para. 87; Klein, op. cit. u bilj. 71, § 4 para. 25.

156 Potacs, op. cit. u bilj. 127, str. 146. 
norme. ${ }^{157}$ Kako zaključuje Gassner, utvrđivanje i ocjena činjenica iz ekonomske perspektive pripada isključivo sferi ekonomske znanosti, a za potrebe primjene prava moguće je isključivo pravno ocjenjivanje činjeničnog stanja (njem. rechtliche Beurteilung des Sachverhalts). ${ }^{158}$

Vrijedi naglasiti da se stajalište o gospodarskom pristupu kao metodi ocjenjivanja činjeničnog stanja može povezati i s terminološkim zabludama oko "prevage (ekonomskog) sadržaja nad (pravnom) formom" prilikom primjene poreznih propisa. Naime, sam naziv ove doktrine ponikle u angloameričkom pravnom krugu može navesti na zaključak da je ključni korak primjene poreznih normi upravo utvrđenje stvarnog ekonomskog sadržaja (ili "supstance") transakcija, aktivnosti ili drugih događaja te da je njihov formalnopravni oblik načelno nevažan. Naprotiv, u okviru pravne države porezni se zahtjev države (njem. Steueranspruch) može temeljiti isključivo na apstraktnom zakonskom opisu oporezivog događaja, koji može biti vezan i uz isključivo formalnopravne kvalifikacije (vidi supra, poglavlje 5.2.). Čak i u slučajevima u kojima se zakonski elementi poreza vežu uz ekonomske pojmove i koncepte, primjenjivači norme ne smiju potpuno ignorirati privatnopravne kvalifikacije činjenica slučaja. ${ }^{159}$ Naime, pogrešna je pretpostavka da su ekonomski sadržaj i pravna forma transakcije uvijek u opreci. Temeljna je funkcija privatnog prava priznavanje i uređivanje faktičnih društveno-gospodarskih odnosa te je stoga u najvećem broju slučajeva pravni položaj stranaka i/ili pravni oblik transakcije doista i usklađen s relevantnim, stvarnim gospodarskim sadržajem. ${ }^{160}$

Zaključno, bez obzira na njezin konkretni normativni izričaj (vidi, primjerice, čl. Il. st. l. OPZ-a), pogrešno je shvaćanje prema kojem doktrina gospodarskog pristupa zahtijeva nekakvu posebnu mehaniku utvrđivanja i ocjenjivanja stvarnog činjeničnog stanja, temeljenu na nalazima ekonomske znanosti i izoliranu od interpretacije mjerodavne porezne norme. Naprotiv, kako je razloženo supra (poglavlje 5.2.), gospodarski pristup ponajprije ima ulogu prilikom (ciljnog) tumačenja propisa. U sferi utvrđivanja činjeničnog stanja prihvatljivo je jedino stajalište kako odredba poput čl. 1l. st. 1. OPZ-a zahtijeva da se u provedbi postupka supsumcije obrati posebna pozornost na smisao i cilj norme, što često upućuje na potrebu procjene ekonomskog sadržaja transakcije ili aktivnosti u

157 Usporedi Klein, op. cit. u bilj. 71, § 4 para. 34.

158 Gassner, op. cit. u bilj. 23, str. 51.

159 Vidi ibid., str. 41 - 42; Tipke i Lang, op. cit. u bilj. 4, str. 8.

160 Vidi Klarić i Vedriš, op. cit. u bilj. 153, str. 24 - 25; Li, J., "Economic Substance": Drawing the Line Between Legitimate Tax Minimization and Abusive Tax Avoidance, Canadian Tax Journal, vol. 54, br. 1, 2006., str. 43. 
pitanju. ${ }^{161}$ To predstavlja potvrdu Gassnerove teze da se u doktrini gospodarskog pristupa zapravo razaznaje temeljni "stav zakonodavca" o tomu kako valja primijeniti porezne norme (vidi supra, poglavlje 5.2.).

\section{ZAKLJUČAK}

Primjena poreznih propisa u svakoj državi nameće složena pitanja, ponajprije pred porezna tijela i nadležne sudove. U pravnom poretku temeljenom na konceptu vladavine prava porezni se propisi moraju primjenjivati na ispravan i metodički primjeren način, što podrazumijeva poznavanje i općih pravila pravnog tumačenja i pojedinih poreznopravnih posebnosti. Cilj je rada bio na pregledan način ocrtati opći teorijski okvir koji može pomoći primjenjivačima poreznih normi, posebice prilikom složenijih slučajeva koji izazivaju dvojbe glede odabira konkretnog rezultata tumačenja. Stoga, ako se prihvati poučak Kurta Lewina kako "nema ništa praktičnije od dobre teorije", nalazi prezentirani u radu mogu pomoći službenicima poreznih tijela, sucima i drugim stručnjacima koji primjenjuju porezne propise.

U tom smislu prvi je važan zaključak da porezno pravo s aspekta njegove primjene i tumačenja nije u biti različito u odnosu na druge pravne grane. Opći metodološki okvir pravnog tumačenja vrijedi i kad je riječ o onom dijelu pravnog sustava koji regulira materiju oporezivanja. Pojedine "posebnosti" u primjeni poreznih propisa, poput doktrine gospodarskog pristupa, ne opravdavaju zaključak kako porezno pravo predstavlja metodološku enklavu unutar (općeg) pravnog sustava. Stoga i u ovom području valja posegnuti za tradicionalnim metodama pravnog tumačenja razvijenim u pravnoj znanosti i sudskoj praksi, poput ciljne, jezične, sistemske i povijesne metode.

Drugo, većina metodoloških posebnosti tumačenja poreznih propisa vezana je uz samu svrhu i prirodu djelatnosti oporezivanja, tj. nametanja i ubiranja poreza. $U$ radu je istaknuto da je tenzija između privatnopravnih i poreznopravnih kvalifikacija nekog odnosa posljedica različitih ciljeva privatnog prava s jedne te poreznog prava s druge strane. Stoga sama uporaba u poreznopravnom kontekstu pojmova "posuđenih" ili "transplantiranih" iz drugih pravnih grana ne dovodi nužno i do prihvaćanja njihova izvornog normativnog značenja. U većem će broju slučajeva, polazeći od cilja relevantne porezne norme, biti potrebno drukčije, šire shvaćanje nekog izvorno privatnopravnog pojma.

161 Vidi Potacs, op. cit. u bilj. 127, str. 147. Usporedi Koenig, op. cit. u bilj. 42, § 4 para. 108. 
Treće, u radu je detaljno obrađena problematika tzv. gospodarskog pristupa ili "prevage sadržaja nad formom" kao najizrazitije metodološke posebnosti u primjeni poreznih normi. Zauzeto je stajalište kako gospodarski pristup, čiji normativni izričaj nalazimo u čl. 11. st. 1. OPZ-a, predstavlja element ciljnog tumačenja s obzirom na to da odražava opći stav ustavotvorca i zakonodavca o raspodjeli poreznog opterećenja sukladno gospodarskoj snazi poreznih obveznika. Najvažniji praktični učinak gospodarskog pristupa očituje se u zabrani slijepog prihvaćanja privatnopravnih kvalifikacija u poreznopravnom kontekstu, bez da se ispita cilj porezne norme. Pri tome je posebno važno utvrđenje vezuje li se zakonski opis oporezivog događaja uz "gospodarsku stvarnost" (npr. kao kod poreza na dohodak) ili za kakve formalnopravne pretpostavke (npr. kao kod poreza na nasljedstva) s obzirom na to da je u potonjem slučaju primjena gospodarskog pristupa isključena.

Osim pravnicima praktičarima, prezentirani nalazi mogu poslužiti i kao podloga za daljnje pravnoznanstvene analize. Od posebne bi vrijednosti bila istraživanja metodike koju porezna tijela i sudovi doista primjenjuju u primjeni i tumačenju poreznih propisa te u kojoj je mjeri u praksi uopće osviještena uloga doktrine gospodarskog pristupa iz čl. 11. st. 1. OPZ-a. Za relativno mladi porezni sustav poput hrvatskoga ozbiljna rasprava u znanstvenoj i stručnoj zajednici o ovim i drugim u radu naznačenim pitanjima od neprijeporne je važnosti ako se teži stvarnom pomirenju koncepta porezne države $s$ jedne te vladavine prava s druge strane.

\section{LITERATURA}

\section{Knjige i članci}

Abreu, A.; Greenstein, R., Tax: Different, Not Exceptional, Administrative Law Review, vol. 71, br. 4, 2019, str. 663 - 717.

Arbutina, H., Ustavna i nadnacionalna ograničenja ovlaštenja na oporezivanje, Zbornik Pravnog fakulteta u Zagrebu, vol. 62, br. 5-6, 2012., str. 1283 - 1322.

Arbutina, H.; Rogić Lugarić, T., Osnove poreznog prava, Narodne novine, Zagreb, 2017.

Avi-Yonah, R. S., The Three Goals of Taxation, Tax Law Review, vol. 60, br. I, 2006., str. $1-28$.

Brooks, N., The Logic, Policy and Politics of Tax Law, u: Edgar, T. et al. (ur.), Materials on Canadian Income Tax, Carswell, Scarborough, 2000.

Bydlinski, F., Juristische Methodenlehre und Rechtsbegriff, Springer, Wien, 2011. 
Bydlinski, F., Pravna metodologija: Osnovi nauke o pravnim metodama, CID, Podgorica, 2011.

Čepulo, D., Vladavina prava i pravna država - europska $i$ hrvatska pravna tradicija $i$ suvremeni izazovi, Zbornik Pravnog fakulteta u Zagrebu, vol. 51, br. 6, 2001., str. $1337-1361$.

Đerđa, D., Neke primjedbe o tumačenju prava, Zbornik Pravnog fakulteta u Rijeci, vol. 23., br. 2, 2002., str. 615 - 643 .

Englisch, J., \& 5 Rechtsanwendung im Steuerrecht, u: Tipke, K.; Lang, J., Steuerrecht, Verlag Dr. Otto Schmidt, Köln, 2015., str. 185 - 224.

Freedman, J., Interpreting Tax Statutes: Tax Avoidance and the Intention of Parliament. The Law Quarterly Review, vol. 123, br. 1, 2007., str. 52 - 90.

Gadžo, S.; Klemenčić, I., Analiza normativnog okvira za sprječavanje zakonitog izbjegavanja poreza u Hrvatskoj: prijedlog izmjena u skladu s pravom Europske unije, Odabrani prijevodi, br. 25, 2014., http://www.ijf.hr/upload/files/file/OP/25.pdf

Gadžo, S., Prilog istraživanju sadržaja načela pravednosti kao kriterija evaluacije normi međunarodnog poreznog prava, Pravni vjesnik, vol. 31, br. 2, 2015., str. 131 - 156.

Gassner, W., Austria, u: Form and Substance in Tax Law, Cahiers de droit fiscal international, vol. 87a, Kluwer, 2002., str. 119 - 152.

Gassner, W., Interpretation und Anwendung der Steuergesetze: kritische Analyse der wirtschaftlichen Betrachtungsweise des Steuerrechts, Wirtschaftsverlag Dr. Anton Orac, Wien, 1972.

Gavella, N., Privatno pravo, Narodne novine, Zagreb, 2019.

Graham, R., A Unified Theory of Statutory Interpretation, Statute Law Review, vol. 23, br. 2, 2002., str. 91 - 134; https://doi.org/10.1093/slr/23.2.91

Heber, C.; Sternberg, C., Germany, u: van Brederode, R. F.; Krever, R. (ur.), Legal Interpretation of Tax Law, Kluwer Law International, Alphen aan den Rijn, 2014., str. 163 - 189.

Johnson, S. R., United States, u: van Brederode, R. F.; Krever, R. (ur.), Legal Interpretation of Tax Law, Kluwer Law International, Alphen aan den Rijn, 2014., str. 319 - 353.

Klarić, P.; Vedriš, M., Građansko pravo: Opći dio, stvarno pravo, obvezno i nasljedno pravo, Narodne novine, Zagreb, 2014.

Klein, F., Abgabenordnung: Kommentar (12. izd.), C.H. Beck, München, 2014.

Koenig, U., Abgabenordnung: AO (3. izd.), C.H. Beck, München, 2014.

Krever, R.; Mellor, P., Australia, u: van Brederode, R. F.; Krever, R. (ur.), Legal Interpretation of Tax Law, Kluwer Law International, Alphen aan den Rijn, 2014., str. 15 - 45. 
Krever, R.; van Brederode, R. F., Legal interpretation of tax law: a reflection on methods and issues, u: van Brederode, R. F.; Krever, R. (ur.), Legal Interpretation of Tax Law, Kluwer Law International, Alphen aan den Rijn, 2014., str. 1 - 14.

Lang, M. et al. (ur.), GAARs - A Key Element of Tax Systems in the Post-BEPS World, IBFD, Amsterdam, 2016.

Li, J., "Economic Substance": Drawing the Line Between Legitimate Tax Minimization and Abusive Tax Avoidance, Canadian Tax Journal, vol. 54, br. 1, 2006., str. 23 - 56.

Lončarić-Horvat, O., Oporezivanje u skladu s načelima pravne države, u: Jelčić, Bo., i dr., Financijsko pravo i financijska znanost, Narodne novine, Zagreb, 2008., str. $526-556$.

Menéndez, A., Justifying Taxes: Some Elements for a General Theory of Democratic Tax Law, Kluwer, Dordrecht, 2001.

Mijatović, N., Teorijsko razmatranje nekih odrednica poreznog sustava, Hrvatska pravna revija, vol. 16, br. 2, 2016., str. 16 - 33.

Núñez Vaquero, Á., Five Models of Legal Science, Revus, vol. 19, 2013., str. 53 - 81; https://doi.org/10.4000/revus.2449

Osterloh, L., Tax Law and Private Law, u: Amatucci, A. (ur.), International Tax Law, Kluwer Law International, Alphen aan den Rijn, 2012., str. 85 - 102.

Peček, R., Formalizam i arbitrarnost u nekim poreznim postupcima, Informator, br. 6394, od 30. 11. 2015., str. 17 - 19.

Popović, D., Poresko pravo, Univerzitet u Beogradu - Pravni fakultet, Beograd, 2018.

Potacs, M., "Wirtschaftliche Betrachtungsweise" als steuerrechtliches Interpretationsprinzip, u: Urnik, S.; Fritz-Schmied, G.; Kanduth-Kristen, S. (ur.), Steuerwissenschaften und betriebliches Rechnungswesen. Strukturen-Prinzipien-Neuerungen. Festschrift für Herbert Kofler, Linde, Wien, 2009., str. 143 - 160.

Pürner, S., Dr. h.c. Enno Becker (1869-1940), Nova pravna revija, br. 2, 2014. , str. $68-74$.

Rogić Lugarić, T.; Bogovac, J., Pravni status poreznih izdataka: stanje i perspektive, u: Bratić, V.; Fabris, M. (ur.), Skrivena javna potrošnja: Sadašnjost i budućnost poreznih izdataka, Institut za javne financije, Zagreb, 2012., str. 175 - 195.

Stoll, G., Bundesabgabenordnung: Kommentar, Verlag Orac, Wien, 1994.

Šinković, Z., Načelo gospodarskog pristupa činjenicama bitnima za oporezivanje, Zbornik radova Pravnog fakulteta u Splitu, vol. 55., br. 1., 2018., str. 201 - 219; https://doi.org/10.31141/zrpfs.2018.55.127.201.

Thuronyi, V., Comparative Tax Law, Kluwer Law International, The Hague, London, New York, 2003.

Tipke, K.; Lang, J., Steuerrecht, Verlag Dr. Otto Schmidt, Koln, 1996. 
Vanistendael, F., Legal framework for taxation, u: Thuronyi, V. (ur.), Tax Law Design and Drafting, International Monetary Fund, Washington D.C., 1996., str. $15-70$.

Visković, N., Argumentacija i pravo, Pravni fakultet u Splitu, Split, 1997.

Visković, N., O tumačenju pravnih akata, Zbornik Pravnog fakulteta u Zagrebu, vol. 31, br. 3-4, 1981., str. 369 - 390.

Visković, N., Teorija prava i države, Birotehnika, Zagreb, 2001.

Vogenauer, F., Sources of Law and Legal Method in Comparative Law, Max Planck Institute for European Legal History Research Paper Series No. 2020-04, https:// papers.ssrn.com/sol3/papers.cfm?abstract_id=3551259 (10. svibnja 2020.).

Vranken, J., Exciting Times for Legal Scholarship, Recht en Methode in onderzoek en onderwijs, vol. 2, br. 2, 2012., str. 42 - 62; https://doi.org/10.5553/ ReM/221225082012002002004

Vrban, D., Država i pravo, Golden marketing, Zagreb, 2003.

Zimmer, F., General Report, u: Form and Substance in Tax Law, Cahiers de droit fiscal international, vol. 87a, Kluwer, 2002., str. 19 - 67.

\section{Pravni akti}

Bundesgesetz über allgemeine Bestimmungen und das Verfahren für die von den Abgabenbehörden des Bundes, der Länder und Gemeinden verwalteten Abgaben (Bundesabgabenordnung - BAO), dostupno na https://www.ris.bka.gv.at/ GeltendeFassung.wxe?Abfrage $=$ Bundesnormen\&Gesetzesnummer $=10003940$

Opći porezni zakon, Narodne novine, br. 115/16, 106/18, 121/19, 32/20, 42/20.

Ustav Republike Hrvatske, Narodne novine, br. 56/90, 135/97, 08/98, 113/00, 124/00, 28/01, 41/01, 55/01, 76/10, 85/10, 05/14.

Zakon o porezu na dobit, Narodne novine, br. 177/04, 90/05, 57/06, 146/08, 80/10, 22/12, 148/13, 143/14, 50/16, 115/16, 106/18, 121/19, 32/20.

Zakon o porezu na dohodak, Narodne novine, br. 115/2016, 106/2018, 121/2019, 32/2020.

Zakon o posebnom porezu na motorna vozila, Narodne novine, br. 15/2013, 108/2013, 115/2016, 127/2017 i 121/2019.

\section{Sudska praksa}

Ustavni sud Republike Hrvatske, odluka br. U-III/1133/2012, od 8. travnja 2014.

Ustavni sud Republike Hrvatske, odluka br. U-III/4285/2013, od 27. rujna 2016. 


\section{Summary}

\section{Stjepan Gadžo*}

\section{APPLICATION AND INTERPRETATION OF TAX LAW: THEORETICAL-NORMATIVE FOUNDATIONS}

The aim of the paper is to present the theoretical and normative fundamentals of the application and interpretation of tax law. Therefore, the author examines the key reference points that law appliers should take into account, regardless of the specifics of the domestic tax law framework. The emphasis is placed on the methodology of applying tax law in the countries belonging to the continental European legal family, such as Croatia. Since tax statutes often make use of concepts and notions originating in private law, special attention is paid to the interrelationship between tax and private law. In addition, the author discusses the doctrine of the so-called "economic approach" or "substance over form" as the most important methodological peculiarity of the interpretation of tax statutes.

Keywords: tax law; legal interpretation; substance over form; economic approach; teleological interpretation

* Stjepan Gadžo, Ph. D., Assistant Professor, Faculty of Law, University of Rijeka, Hahlić 6, 51000 Rijeka, Croatia; sgadzo@pravri.hr;

ORCID ID: orcid.org/0000-0002-1905-5330 